\title{
Reservoir quality controls on Rotliegend fluvio-aeolian wells in Germany and the Netherlands, Southern Permian Basin - Impact of grain coatings and cements
}

\author{
Benjamin Busch $^{\mathrm{a}, *}$, Christoph Hilgers ${ }^{\mathrm{a}}$, Dirk Adelmann ${ }^{\mathrm{b}}$

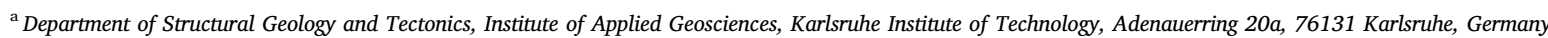 \\ ${ }^{\mathrm{b}}$ Wintershall Dea GmbH, Friedrich-Ebert-Straße 160, 34119 Kassel, Germany
}

\begin{abstract}
A B S T R A C T
Keywords:

Reservoir quality evolution

Grain coatings

Diagenesis

Reservoir quality in sandstones can be a function of temperature, pressure, and chemical alterations over time. Some intrinsic properties of sandstones can additionally impact the evolution of reservoir quality. The detrital composition, depositional environment, and properties controlled thereby, dictate some of the diagenetic changes. Extrinsic processes, like external fluids, e.g. from hydrothermal events or dewatering of clay minerals, can additionally result in changes of reservoir quality. One of these properties are grain coatings on quartz grains, which can strongly affect pore cementation by quartz overgrowths. To predict and infer the quality of undrilled reservoirs, constraints are needed to predict their occurrence. We analyse two reservoir settings in the Southern Permian Basin and delineate the impact of depositional systems, lithologies, detrital and authigenic composition on reservoir quality and with regard to grain coatings. Results highlight the importance of diagenetic alterations and the source area in regards to burial development in different parts of the Southern Permian Basin. Samples from the Rotliegend Bahnsen Sandstone Member from Germany and the Slochteren Sandstone Formation from the Netherlands have been petrographically and petrophysically analysed and linked to depositional environments. Our data shows that the emplacement and presence of grain coating minerals cannot be simply linked to the depositional environment or processes controlled thereby (e.g. grain size and sorting), neither on a reservoir-, nor on a basin scale. The dissolution of alumosilicates additionally has no consistent impact on the authigenesis of chloritic grain coatings on the reservoir- or basin scale in this study. This implies the necessity of sample specific analyses and importance of the assessment of diagenetic alterations when analysing, modelling, or predicting reservoir quality in similar settings worldwide.
\end{abstract}

\section{Introduction}

Grain coatings can impact the formation of syntaxial quartz over growth cements and can thus be a primary control on reservoir quality in siliciclastic reservoirs (Storvoll et al., 2002; Ajdukiewicz and Larese, 2012). The main control is not the simple presence of grain coatings, but how much of the surface area of substrate grains is covered (Heald and Larese, 1974; Walderhaug, 1996). To describe this, the term grain coating coverage is used, regardless of the mineral phase coating the grains. Grain coatings are present in many sandstone lithologies (Dowey, 2012; Dowey et al., 2012, 2017) and their characteristics and genesis are subject to many recent applied and fundamental research projects (Ehrenberg, 1993; Ryan and Reynolds, 1996; Aagaard et al., 2000; Storvoll et al., 2002; Billault et al., 2003; Needham et al., 2005; Esch et al., 2008; Mahaney et al., 2010; Ajdukiewicz and Larese, 2012;
Dowey, 2012; Dowey et al., 2012, 2017; Fischer et al., 2013; French and Worden, 2013; Haile et al., 2015; Busch et al., 2017; Wooldridge et al., 2017, 2019a, 2019b; Molenaar and Felder, 2018; Molenaar et al., 2019). Their distribution, occurrence, and properties in different lithologies in dependence of differing depositional properties still re quires attention.

We present analyses of grain coating occurrences in fluvio eolian Rotliegend sandstones from two parts of the Central European Southern Permian Basin and integrating the impact of diagenetic pathways on subsurface reservoir properties. In the presented samples, illite, chlorite (and smectite mixed layer clays of both minerals), and hematite are the main grain coating minerals.

Prominent grain coatings show a variety of textures and terms which are described as tangential pore lining clay minerals (Fig. 1, A), subtangential (Fig. 1, H) to radial clay minerals (Fig. 1, B, G), and

\footnotetext{
* Corresponding author.

E-mail address: benjamin.busch@kit.edu (B. Busch).
} 


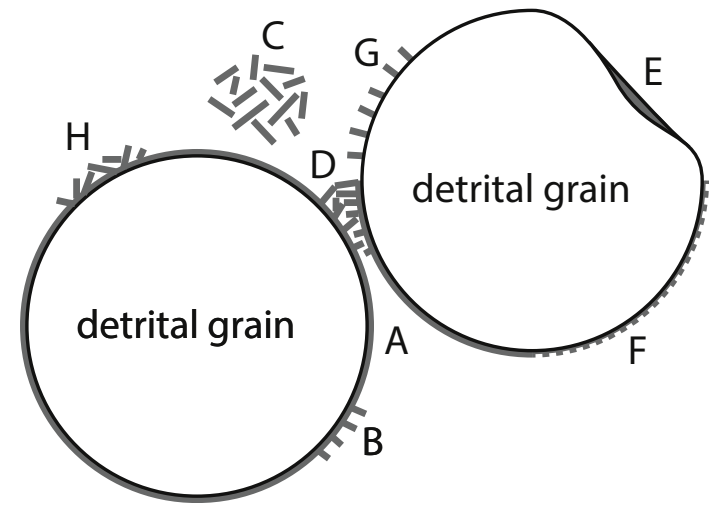

Fig. 1. Schematic grain coating textures observed in thin sections. A: tangential grain coating (cutan) B: radial clay mineral coatings, mostly nucleating on tangential substrates. C: mesh-like pore-filling clay mineral cements without connection to the detrital grains. D: pore-bridging radial clay mineral. E: Thick clay mineral or hematite coatings, especially pronounced in grain indentations. F: Pigmented dust rims. Mostly hematite. G: Radial clay mineral coating, occasionally without an apparent tangential substrate in the field of view. $\mathrm{H}$ : radial to sub-tangential clay mineral coating.

pigmented rims (Fig. 1, F). Throughout this study tangential pore lining clay minerals are referring to clay minerals aligned parallel to the grain surface, often especially pronounced in indentations on the grain sur face (Fig. 1, A, E). In other literature they are also called cutans, tan gential compacted illite (Type A), clay drapings, or illite coatings (IC) (Gaupp et al., 1993; Zwingmann et al., 1998; Liewig and Clauer, 2000). Subtangential or radial grain coating clay minerals are described to be oriented perpendicular or subperpendicular to the grain surface (Fig. 1, $\mathrm{B}, \mathrm{G}, \mathrm{H})$. They grow into the pore space and may nucleate on pre ex isting tangential pore lining clay minerals. The continued growth of clay minerals in this configuration may lead to pore bridging textures (Fig. 1, D) (Gaupp et al., 1993). They have also been termed radial grain coatings or Type C (Liewig and Clauer, 2000). The occurrence of largely pore filling aggregates may appear mesh like in thin section with no apparent interaction with detrital grains (Fig. 1, C). The mesh like texture was also termed meshwork clay minerals (Gaupp et al., 1993), or Type B illite (Liewig and Clauer, 2000). Hematite mostly occurs as a pigmented rim (Fig. 1, F) or as thick layers in grain indentations (Fig. 1, E). These occurrences in grain indentations might also contain up to $50 \%$ of clay minerals (Hasner, 2004). The thicker hematitic grain coatings in grain embayments are mostly interpreted as inherited rims, abraded on other convex surfaces. They are effective inhibitors of later syntaxial quartz cement growth (e.g. Busch et al., 2017) but may not act as substrate for later clay mineral growth.

The formation of detrital or diagenetic clay mineral grain coatings on quartz grains is mainly governed by the supply of (1) clay minerals to act as precursor mineral phases on grains, (2) the influence of me teoric and formation waters, and (3) the subsequent diagenetic pathway (Ajdukiewicz et al., 2010, Table 1). Precursory clay coatings are dis cussed to be formed either by illuviation or infiltration of clay minerals, blown into the sedimentary system and percolated into the sediment by water (Seemann, 1982, Table 1; Ajdukiewicz et al., 2010). These pre cursor clay mineral grain coatings can be altered and recrystallized during burial (Aagaard et al., 2000). Alternatively, grain coatings can form in situ during late early to burial diagenesis as a result of dis solution of unstable alumosilicates or rock fragments, e.g. volcanic rock fragments, and precipitation on surrounding detrital grains (Anjos et al., 2000; Liewig and Clauer, 2000; Grigsby, 2001; Anjos et al., 2003; Bahlis and De Ros, 2013). The growth of illite grain coatings from so lutions in the pore space was also experimentally shown to be effective in forming clay mineral grain coatings (Haile et al., 2015). In an ex perimental study, Needham et al. (2005), also highlight the formation of clay rims by macrobiotic sediment ingestion and excretion as an analogue to marine depositional environments.

Other factors controlling the occurrence and extent of grain coating coverages have been controversially discussed (Table 1). For example, some of the models ascribe higher grain coating coverage to finer grain size, others state a more complete grain coating coverage is found in coarser grains (Walker, 1979; Bloch et al., 2002; Ajdukiewicz et al., 2010; Darbha et al., 2012).

Additionally, the timing of illite or chlorite formation during early diagenesis or burial diagenesis is essential (e.g. Liewig and Clauer, 2000; Anjos et al., 2003) (Table 1). For example, fibrous illite, which can appear e.g. pore lining or forming a radial rim on quartz grains, can inhibit later burial diagenetic quartz cementation. These radial illite phases can nucleate on smectitic/illitic substrates (Gaupp et al., 1993; Molenaar and Felder, 2018), but are also documented to form without a substrate (Liewig and Clauer, 2000). This later diagenetic clay rim phase may contribute to the preservation of porosity and is solely governed by burial diagenetic alteration. Whilst small volumes of illitic grain coatings may be beneficial for reservoir quality, formation da mage and permeability reduction by the growth of large quantities of illite in the pore space may deteriorate reservoir quality (e.g. Civan, 2007).

Differences in the development and presence of grain coatings have previously been related to the depositional environments (Matlack et al., 1989; Pittmann et al., 1992; Wilson, 1992; Shammari et al., 2011; Dowey et al., 2012; Wooldridge et al., 2019b).

Variations in early diagenetic assemblages governed by the de positional environment including, but not limited to, aeolian systems are well studied and described for multiple settings (Seemann, 1982; Anjos et al., 2000; Morad et al., 2000, 2010; Ramm, 2000; Bloch et al., 2002; Ketzer et al., 2002; Elias et al., 2004; El Ghali et al., 2006; Hammer et al., 2010; Shammari et al., 2011; Bjørlykke, 2014; Henares et al., 2014; Khalifa and Morad, 2015; Marchand et al., 2015; Lan et al., 2016). However, for grain coatings, their distribution and occurrence is more uncertain (Haile et al., 2015; Wooldridge et al., 2017, 2019b). Only distributions for few depositional environments could be estab lished (Ehrenberg, 1993).

Some studies focused on other controlling factors in aeolian systems and derived the influence of meteoric waters during illuviation (Moraes and De Ros, 1992) and the role of ground water chemistry (Ajdukiewicz et al., 2010). These studies show that the formation of chlorite grain coatings from smectitic precursor minerals is favoured in hypersaline ground waters (Ajdukiewicz et al., 2010). Additionally, the stabilising effect of vegetation and microbial activity, e.g. formation of biofilms, were identified to impact the emplacement, preservation or formation of grain coatings in recent depositional systems (Esch et al., 2008; Welton, 2015). Pedogenesis has recently been discussed as an effective formation factor for tangential illitic grain coatings (clay cutans) in the Dutch offshore sector (Molenaar and Felder, 2018). In areas with low accommodation rates within the Southern Permian Basin, extensive aridisol development including grain coating textures were recently identified (Molenaar et al., 2019). The studied area in Lithuania enables the study of primary textures due to the limited maximum burial depth (Molenaar et al., 2019).

Additionally, grain size and sorting may have a direct impact on the presence and extent of grain coatings which is then altered during di agenesis, including depositional systems other than the fluvio aeolian (Walker, 1979; Matlack et al., 1989; De Ros et al., 1994; Remy, 1994; Aagaard et al., 2000; Bloch et al., 2002; Anjos et al., 2003; Ajdukiewicz et al., 2010; Shammari et al., 2011; Darbha et al., 2012; Bahlis and De Ros, 2013; Dowey et al., 2017; Wooldridge et al., 2017; Molenaar and Felder, 2018). Grain size and sorting strongly affect the porosity of sediments (Rogers and Head, 1961). In regional studies, a larger grain coating coverage has been linked to smaller grain size in both fluvio aeolian sandstones and estuarine deposits (Shammari et al., 2011; Wooldridge et al., 2017; Molenaar and Felder, 2018). Sorting is pre sented in Dowey et al. (2017) to affect the mean grain coated surface 
Table 1

Compilation of controlling factors on the presence and extent of grain coatings.

\begin{tabular}{|c|c|c|}
\hline Name & Description & Reference \\
\hline Grain size & $\begin{array}{l}\text { Coarser grains have less specific surface area, require less clay material to be well } \\
\text { coated than finer grains. }\end{array}$ & Bloch et al. (2002) \\
\hline Grain size II/Dune mobility & $\begin{array}{l}\text { Smaller grains are able to better retain coatings during transport and abrasion in } \\
\text { mobile aeolian dune settings, due to a more rugose surface }\end{array}$ & $\begin{array}{l}\text { Ajdukiewicz et al. (2010),Walker (1979), Darbha } \\
\text { et al. (2012) }\end{array}$ \\
\hline Meteoric waters & Periodic phases of wetting and drying to form most complete coatings & Ajdukiewicz et al. (2010) \\
\hline Ground water & $\begin{array}{l}\text { High salinity of groundwater during early diagenesis may result in authigenesis of } \\
\text { chlorite coatings }\end{array}$ & Ajdukiewicz et al. (2010) \\
\hline Wind direction & $\begin{array}{l}\text { Impact on grain size or texture of sediment and following alteration of grain coating } \\
\text { properties plus source for airborne dust and transport medium for dust before settling }\end{array}$ & Ajdukiewicz et al. (2014), Esch et al. (2008) \\
\hline Source area for inherited rims & Inherited rims from ephemeral fluvial deposits & Esch et al. (2008) \\
\hline Rock fragments & Burial diagenetic alteration of ferromagnesian grains to chlorite can form coatings & $\begin{array}{l}\text { De Ros et al. (1994), Remy (1994), Anjos et al. } \\
\text { (2003), Bahlis and De Ros (2013) }\end{array}$ \\
\hline Authigenesis & Radial, pore lining illite in burial diagenesis, as result of hyperthermal event. & Liewig and Clauer (2000) \\
\hline Authigenesis II & Radial illite found in early near-surface diagenesis in phreatic zones & Ajdukiewicz et al. (2010) \\
\hline Early cementation & $\begin{array}{l}\text { Early pore filling carbonate and sulfate cementation in arid setting might prevent the } \\
\text { infiltration, illuviation, and formation of early cutan-type clay coatings }\end{array}$ & Morad et al. (2000) \\
\hline $\begin{array}{l}\text { Changes in grain coating coverage } \\
\text { during mesogenesis }\end{array}$ & $\begin{array}{l}\text { Final coating characteristics develop during recrystallization of precursor mineral } \\
\text { phase }\end{array}$ & Aagaard et al. (2000) \\
\hline Geology-Biology Interaction & $\begin{array}{l}\text { Vegetation or microbially induced biofilms stabilize early grain coatings, macrobiotic } \\
\text { sediment ingestion and excretion }\end{array}$ & $\begin{array}{l}\text { Welton (2015), Esch et al. (2008), Needham et al. } \\
\text { (2005) }\end{array}$ \\
\hline Pedogenesis & Tangential illite rim cements formed by pedogenetic processes & $\begin{array}{l}\text { Molenaar and Felder (2018), Molenaar et al. } \\
\text { (2019) }\end{array}$ \\
\hline
\end{tabular}

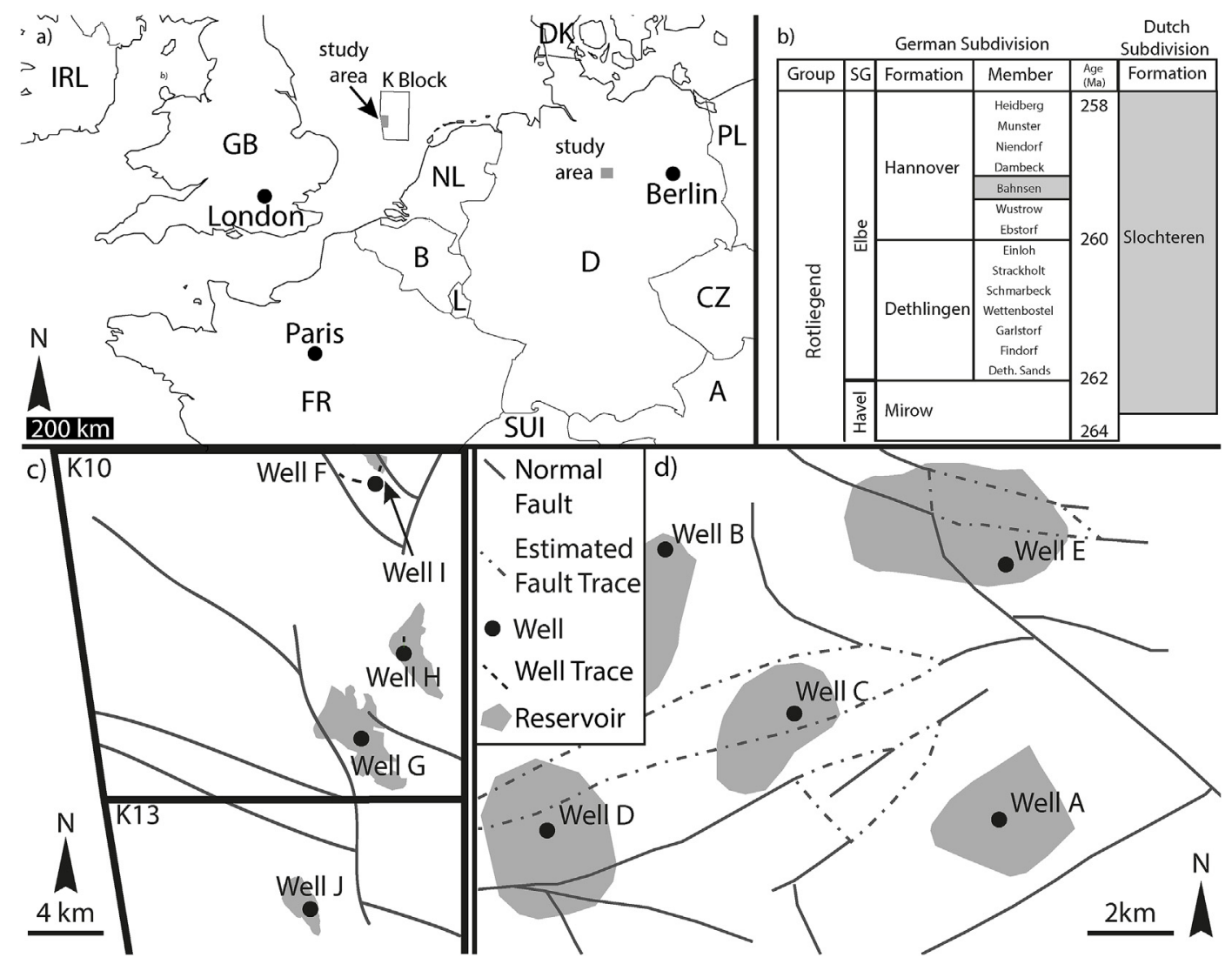

Fig. 2. a) Location of the studied areas in Europe. b) Stratigraphic ages of all studied deposits (grey boxes) (based on Menning (1995); Deutsche Stratigraphische Kommission (2002)). c) Structural Map of the Base Zechstein from the Dutch offshore K10 and part of K13 block (Slochteren formation), highlighting the well locations and large-scale structural elements (Structural elements extracted from Duin et al., 2006). d) Structural map of the Top Rotliegend from NE-Hannover (Bahnsen Sandstone formation), highlighting the position of wells in respect to one another and large-scale structural elements.

area of modern sands in estuaries. The poorer the sorting the greater is the coverage of the surface area of sand grains (Dowey et al., 2017). Dowey et al. (2017) also evaluated the skewness of the grain size dis tribution and presented a correlation of a larger mean grain coating coverage with a skewness towards fine and very fine grain size.

The delineation of universal trends linking coating coverage with those parameters within the fluvio aeolian system could prove bene ficial to reservoir quality assessment. The term universal in this case reflects the ability to sufficiently reproduce observed and measured amounts of grain coatings in the two studied regions within the Southern Permian Basin.

In this study, the reservoir properties, i.e. porosity and permeability, 
of a total of ten wells are comparatively studied in two areas on a large intra basin scale (approx. $500 \mathrm{~km}$ apart, Fig. 1 a). The impact of the depositional environment, grain size, sorting, and detrital grains on grain coatings, possibly controlling reservoir properties, is presented and discussed in a diagenetic framework to aid petrographers, reservoir geologists, diagenetic forward modelers in assessing the risk of working with analogue data.

The main questions of this work are:

1) Is the presence and extent of grain coating minerals controlled or influenced by the depositional environment, grain size, sorting or detrital grains in the Rotliegend in NW Europe? I.e. do dune sand stones feature larger clay coating coverages than dry sandflat de posits, or vice versa, affecting reservoir quality?

2) Can the presence and extent of grain coating minerals be predicted or estimated in other fluvial aeolian sedimentary rocks based on any of the presented criteria, irrespective of the diagenetic pathways (including various pressure temperature time conditions) for the Rotliegend in NW Europe?

3) Do the controlling factors, established in sediments and some sedi mentary rocks, apply to a sedimentary rock that underwent diage netic alteration in the Rotliegend in NW Europe?

\section{Geological setting}

The deposits of two different study areas of fluvio aeolian Permian Rotliegend strata from the Permian Basin System have been compara tively studied. Nine of the studied wells penetrate nine different gas reservoirs. One well only had gas shows following completion, but was never produced. Samples of five wells penetrating the Bahnsen Sandstone Member, NE of Hannover, and five wells penetrating the Slochteren Sandstone Formation, in the Dutch offshore K10 and K13 blocks, were evaluated (Fig. 2 a d). The areas were chosen to present different provenances and burial histories (Fig. 3 a, b), while both settings are comparable in terms of sedimentary structure and inter preted depositional environments. In both settings the studied wells are less than $10 \mathrm{~km}$ apart. All well samples follow comparable porosity permeability trends, which are a basis to compare the differences in grain coating development across different wells from the same area. Although the source areas and depositional ages differ for NE Hannover and the Dutch offshore, a universal impact of four indicators, which are commonly used in literature, was tested in the analysed sample series: Depositional environment, grain size, sorting, and detrital grains. In total, 172 samples from the subsurface originate from Germany (50) and the Dutch North Sea (122).

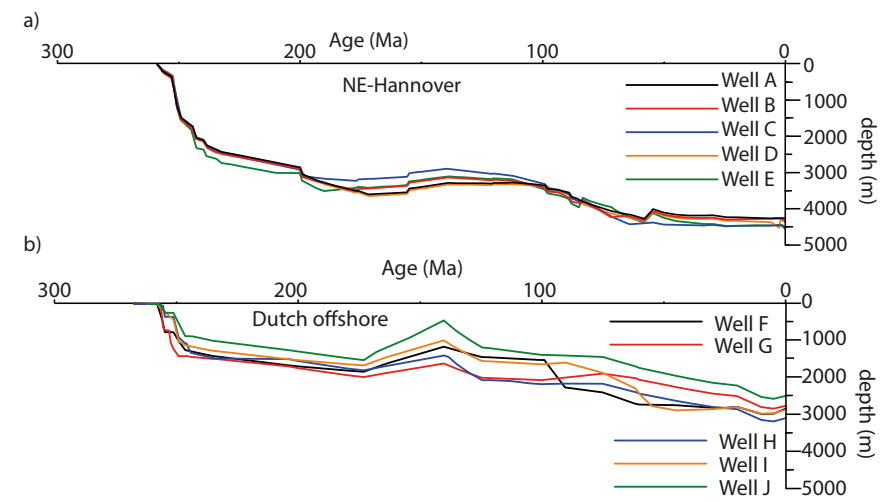

Fig. 3. a) Burial reconstructions of the wells from NE-Hannover. b) Burial reconstructions of the wells from the Dutch offshore. Overall, samples from NEHannover have experienced deeper burial and were exposed to higher temperatures than the samples from the Dutch offshore. (For interpretation of the references to colour in this figure legend, the reader is referred to the Web version of this article.)
(1) NE Hannover sample set, Germany (wells A, B, C, D, E)

The sediments of the Bahnsen Sandstone were deposited on the southern margin of the Southern Permian Basin. Deposition took place in a N S striking graben (Gast et al., 2010), in a semi arid fluvio aeolian setting. The overall setting is controlled by cyclic lacustrine intercala tions as studied in other Rotliegend settings (Rieke, 2001; Gast et al., 2010). Sediments are sourced from alluvial fans at the Variscan mountain belt towards the south, transporting clastic material to the basin center (Katzung, 1975; Lutz et al., 1975). During deposition, the prevailing wind direction is from the NE (Glennie, 1982; George and Berry, 1994). The Rotliegend of the area is overlain by Zechstein eva porites, occasionally forming salt pillows (Gast et al., 2010). Wells A, B, C, D and E are situated on the Pompeckj Block which is part of the Southern Permian Basin System (Gast et al., 2010) (Fig. 2 d). The sampled lithologies are presently at $42644570 \mathrm{~m}$ TVD (Busch et al., 2018) (Fig. 3). Wells A to E were producing gas from the Rotliegend Bahnsen Sandstone.

\section{(2) Dutch Slochteren Sandstone samples (wells F, G, H, I, J)}

The sediments of the Slochteren Formation were deposited in the south western part of the Southern Permian Basin. This area was in verted during the Late Jurassic and Early Cretaceous and now forms a transition between the Broad Fourteens Basin and the Cleaver Bank High (Verweij, 2003). Generally, NE wind directions and the meteoric water supply control the deposition of sediments in this arid to semi arid setting (Glennie, 1983; George and Berry, 1994). The source areas of those sediments are the Anglo Brabant Massif and Rhenish Massif located to the South of the studied area (George and Berry, 1994; Verweij, 2003). Four wells (F I) are situated in block K10 on the Cleaver Bank High, and one well is situated in block K13 (well J) at the margin of the Broad Fourteens Basin (Fig. 2 c). The burial path and subsequent erosion differs from a well at the margin of the Broad Fourteens Basin as opposed to the deposits of the Cleaver Bank High (Roos and Smits, 1983; Verweij, 2003, their Fig. 18) (Fig. 3). Sampled lithologies are currently between 2479 and $3117 \mathrm{~m}$ TVD, which re presents the maximum burial depth. Well $\mathrm{F}$ had gas shows after com pletion, whereas gas was produced from wells $\mathrm{G}$ to $\mathrm{J}$.

\section{Materials and methods}

The delineation of dependencies governed by the depositional en vironment was based on core description of the lithologies. Sample analysis was mainly performed on thin sections dyed with blue epoxy resin and assisted by SEM analyses. Samples from well F J were ad ditionally stained with Alizarin Red $S$ to differentiate carbonate ce ments. The SEM and SEM EDX analyses were performed with a JEOL JSM7000F at the Central Facility for Electron Microscopy (GFE), RWTH Aachen University, at an acceleration voltage of $15 \mathrm{kV}$ and a working distance of approximately $10 \mathrm{~mm}$.

The evaluation of modal compositions is based on point counting (300 steps) on thin section samples from NE Hannover. The modal compositions of Dutch samples (well $\mathrm{F} \mathrm{J}$ ) are documented in internal reports, from which the relevant data was extracted and quality con trolled by additional point counting. The modal composition of some samples are presented in sedimentological or petrographic reports, available for each well in the online portal of NLOG (2018, links in the references), created by TNO. The evaluation of grain coating coverages was performed for all samples from NE Hannover and the Dutch Slochteren Sandstone on 50 grains per sample (e.g. Taylor et al., 2004; Busch et al., 2017) on thin sections using a Leica DM LP transmitted light microscope by one operator. Grains were analysed along a grid sub perpendicular to bedding observable in thin sections. In this study, we separately point count tangential pore lining clay minerals, and pore filling clay minerals, the latter of which includes radial and 
meshwork clay mineral textures. The coverage of grains by grain coatings is the surface fraction of a grain, which is in contact with the intergranular volume (IGV) and coated by a mineral phase other than syntaxial overgrowths, cements, or matrix. Grain contacts are omitted. The IGV is defined after Paxton et al. (2002), as the sum of inter granular porosity, intergranular cements and depositional matrix. For each grain, the grain coating coverages are compared to comparator images of measured grain coating coverages as the fraction of grain surface area in contact with the IGV. They are accordingly classified on a scale from $0 \%$ (no grain coating present) to $100 \%$ (complete grain coating) in subdivisions of $10 \%$. Pigmented hematite rims are classified as $5 \%$. Thicker, more continuous hematite seams are classified ac cordingly. Averaging per sample resulted in the grain coating coverage. This amounts to a total of 8.600 grain coating analyses in this dataset. The measurements of grain sizes were performed on the long axis of at least 100 grains per sample on a grid adjusted to the maximum ob served grain size (Busch et al., 2017). Trask sorting (Trask, 1930) was calculated from these measurements.

Petrophysical parameters (porosity and permeability) were mea sured on one inch $(2.54 \mathrm{~cm}$ ) core plugs. The data was extracted from internal reports and the measurement procedures are outlined below.

Porosities of samples from the Bahnsen Sandstone member were measured using Archimedes' method with iso propanol being the dis placed fluid. Porosities of samples from the Slochteren Sandstone Formation were measured by He pycnometry. Apparent permeabilities for samples from NE Hannover were measured in a commercial steady state setup using air as a permeant with confining pressures of up to a maximum of $2 \mathrm{MPa}$ ( $290 \mathrm{psi}, 20 \mathrm{bar}$ ). Klinkenberg corrected perme abilities for samples from the Slochteren Sandstone Formation were measured using air as a permeant. A sample was placed in a Hassler type core holder at a confining pressure of $2.76 \mathrm{MPa}$ (400 psi, 27.6 bar).

The following scheme was used to coherently interpret the deposi tional environment of sediments in core material to assign a specific depositional environment for each of the analysed samples. Following a classification scheme based on previous work in the siliciclastic Rotliegend (Antrett, 2011; Vackiner, 2011), the following sediment types were distinguished: aeolian dune, dry sandflat, damp sandflat, wet sandflat, low energy fluvial, lacustrine deposits, and lake margin deposits (Table 2).

\section{Results}

\subsection{Lithotypes}

In this study, 47 samples were taken from aeolian dune deposits and 63 samples were interpreted as dry sandflat deposits. Damp and wet sandflats represent 29 and 5 samples, respectively. Fluvial deposits were sampled 25 times, and lake margin deposits were sampled 3 times.

Cores from NE Hannover include all interpreted depositional en vironments, but low energy fluvial and wet sandflat deposits were not sampled. Cores and samples from the Dutch offshore cover the full range of depositional environments (Fig. 4).

\subsection{Reservoir properties}

All samples show a positive correlation of porosity and permeability (Fig. 5, Tab. 3). In absolute terms, samples from NE Hannover range in porosity from 0.9 to $20.6 \%$, with an average porosity of $6.4 \%$. Apparent permeabilities in NE Hannover range from 0.01 to $122 \mathrm{mD}$, with an average of $8.8 \mathrm{mD}$.

Samples from the Slochteren Sandstone show porosity values in the range of $2.729 .6 \%$, with an average of $18.7 \%$. Permeability values range from 0.13 to $2120 \mathrm{mD}$, with an average of $183.8 \mathrm{mD}$.

Generally, the Slochteren Sandstone samples show higher porosities and permeabilities compared to the Bahnsen Sandstone samples. In both sample series, a correlation of reservoir properties and well loca tion is not clearly recognizable (Fig. 5).

\subsection{Petrography}

\subsubsection{Detrital and authigenic composition}

The detrital composition of samples from NE Hannover mainly consists of quartz (48 69.3\%, mean: $58.7 \%$ ), feldspars (4.3 15\%, mean: $9 \%$ ), rock fragments (0 7.7\%, mean: $2.2 \%$ ), accessories (mica, zircon, tourmaline, TiO2, $01.3 \%$, mean: $0 \%$ ), iron oxide grains (0 5.7\%, mean: $0 \%$ ), and depositional matrix (0 5.7\%, mean: 0.7\%) (Fig. 6). Rock fragments are mainly silicic and feldspathic volcanic rock frag ments, metamorphic rock fragments (phyllites and undifferentiated metamorphics), and sedimentary rock fragments (shale, siltstone, and sandstone rock fragments).

Samples from NE Hannover fall in the field of subarkoses plotted after Folk (1980) (Fig. 7).

The authigenic constituents are quartz cement (1.7 22.7\%, mean: $9 \%$ ), feldspar cement (0 2.7\%, mean $1 \%$ ), carbonate cements (0.3 16.3\%, mean: 4.7\%), sulfate cements (anhydride and barite, 0 20\%, mean: $2.5 \%$ ), illite cements (0 13\%, mean: $0 \%$ ), chlorite ce ment ( 0 7.7, mean: $0 \%$ ), and iron oxide cements ( $0.7 \%$, mean: $0 \%$ ). Replacive cements are carbonates ( 0.3 , mean: $0 \%$ ), illite ( $02.7 \%$, mean: $1 \%$ ), and chlorite ( $01 \%$, mean: $0 \%$ ). Other phases are hydro carbons/bitumen, ranging from 0 to $4 \%$, with a mean of $0 \%$. Carbonate cements are composed of calcite. Petrographically determined inter granular porosity ranges from 0 to $12.7 \%$ (mean: $1.8 \%$ ), while in tragranular porosity ranges from 0 to $2.3 \%$ (mean: $0.33 \%$ ) (Fig. 6).

The detrital constituents of Dutch offshore samples are mainly quartz (4.9 76.54\%, mean: 56.9\%), feldspars (0 8\%, mean: 0.3\%), rock fragments (0.9 19.8\%, mean: 4.9\%), accessories (mica, zircon, tour maline, TiO2, 0 9.9\%, mean: $1 \%$ ), and depositional matrix (0 79.5\%, mean: 3\%) (Fig. 8). Rock fragments are mainly metamorphic rock fragments (phyllites, schist, gneiss), feldspathic and siliceous volcanic rock fragments, and sedimentary rock fragments (shale, siltstone, and

Table 2

Overview of criteria to distinguish the depositional environment from core material.

\begin{tabular}{|c|c|c|}
\hline Depositional Environment & Characteristic & Reference \\
\hline Aeolian Dune & $\begin{array}{l}\text { well-bedded, fine to coarse grained sandstone, unimodal dip, bimodally sorted, grain fall- and } \\
\text { grain flow laminae }\end{array}$ & Anderson (1988), Fryberger et al. (2011) \\
\hline Dry Sandflat & well bedded or homogeneous, fine to coarse grained sandstone, bedding generally less than $5^{\circ}$ & Mountney and Jagger (2004) \\
\hline Damp Sandflat & $\begin{array}{l}\text { fine to medium grained sandstone, silt and clay content up to } 20 \% \text {, wavy lamination, can } \\
\text { contain soft sediment deformation }\end{array}$ & $\begin{array}{l}\text { Amthor and Okkerman (1998), van den Belt and } \\
\text { van Hulten (2011) }\end{array}$ \\
\hline Wet Sandflat & $\begin{array}{l}\text { very-fine to fine sandstone, silt and clay content between } 20 \text { and 50\%, poor sorting, wavy } \\
\text { lamination, can contain soft sediment deformation }\end{array}$ & $\begin{array}{l}\text { Amthor and Okkerman (1998), van den Belt and } \\
\text { van Hulten (2011) }\end{array}$ \\
\hline Low-energetic Fluvial & $\begin{array}{l}\text { clay to coarse sandstone or conglomerate, can contain rip-up clasts in rather homogeneous } \\
\text { sandstone matrix }\end{array}$ & Fryberger et al. (2011) \\
\hline Lacustrine & $100 \%$ structureless or laminated shale & Fryberger et al. (2011) \\
\hline Lake Margin & $\begin{array}{l}\text { irregular cm-scale intercalations of poorly sorted, structureless sandstone in shale, grading into } \\
\text { lacustrine deposits }\end{array}$ & Antrett (2011) \\
\hline
\end{tabular}




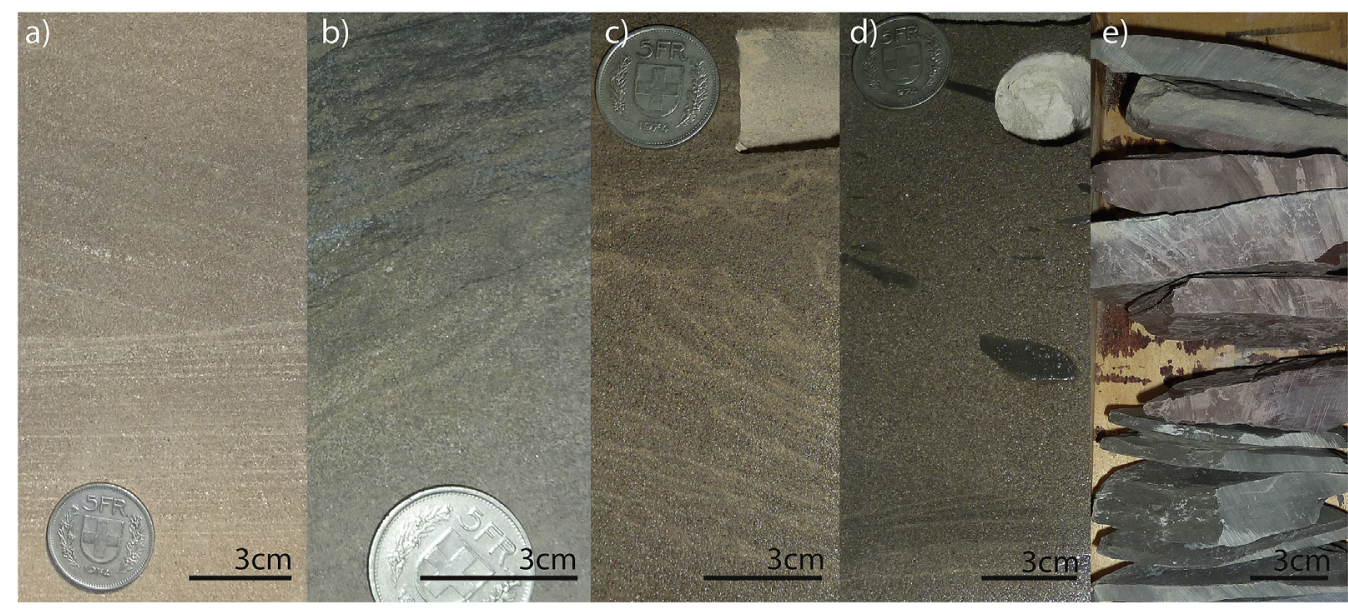

Fig. 4. Lithological associations examples from the Dutch offshore region. a) Top: pin stripe laminated, cross bedded dune sandstone, bottom: horizontally laminated dry sandflat containing deflation layers (Well J, $2520 \mathrm{~m}$ TVD). b) Wavy lamination in clay-richer damp sandflat environments (Well H, 3088 m TVD). c) Irregular lamination in clay rich $(>50 \%)$ wet sandflat deposits (Well H, 3109 m TVD). d) fluvial deposits occasionally containing clay rip-up clasts (Well H, $3100 \mathrm{~m}$ TVD). e) Lacustrine deposits consisting of occasionally finely laminated clay. Where the lithologies are bleached, the clay layers show reaction horizons towards the over- and underlying sandstones (Well H, $3090 \mathrm{~m}$ TVD). (For interpretation of the references to colour in this figure legend, the reader is referred to the Web version of this article.)
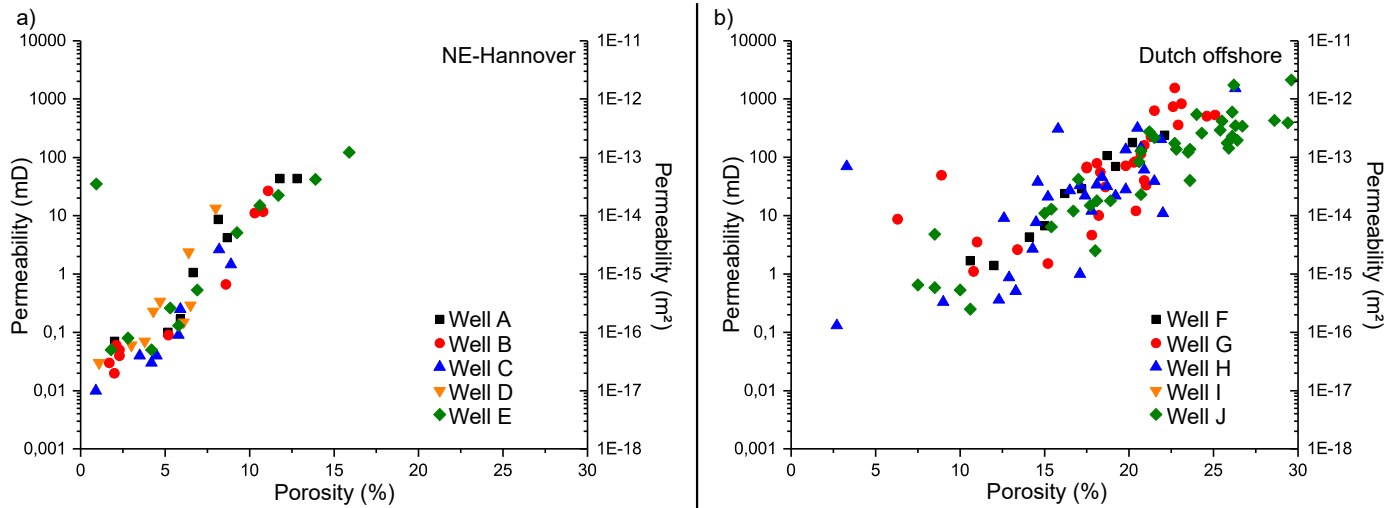

Fig. 5. a) Porosity-permeability cross plot of the studied samples from NE-Hannover revealing a porosity permeability correlation, regardless of the well. b) Porositypermeability cross plot of the studied samples from the Dutch offshore revealing a porosity permeability correlation, regardless of the well. The porosities and permeabilities of samples from the Netherlands are slightly higher. (For interpretation of the references to colour in this figure legend, the reader is referred to the Web version of this article.

sandstone rock fragments).

Samples from the Slochteren Sandstone Formation show a higher variation in detrital composition, featuring quartzarenites, subarkoses, sublitharenites, litharenites and lithic arkose when plotted according to Folk (1980) (Fig. 7).

The authigenic constituents are quartz cement (0 5.9\%, mean: $0.9 \%)$, feldspar cement $(01 \%$, mean $0 \%)$, carbonate cements (0.3 24.9\%, mean: 7\%), sulfate cements (anhydride and barite, 0 5.3\%, mean: $0.3 \%$ ), illite cements ( $06.1 \%$, mean: $1 \%$ ), and kaolinite cement (0 20, mean: 6.9\%). Other phases are hydrocarbons/bitumen, ranging from 0 to $4 \%$, with a mean of $0 \%$. Carbonate cements are mainly dolomitic. Petrographically determined intergranular porosity ranges from 0 to $27.8 \%$ (mean: $14.8 \%$ ) (Fig. 8 ).

\subsection{Grain coatings}

The grain coating coverage of all samples ranges from very low coverages $(\sim 5 \%)$ to very high coverages $(\sim 97 \%)$ (Tab. 3$)$. Their impact on quartz cementation becomes evident at grain coating coverages above $\sim 80 \%$ (Fig. 9) in the NE Hannover sample series. The average quartz cement volume at grain coating coverages $<80 \%$ is $11.23 \%$ and $>80 \%$ is only $6.04 \%$. At large grain coating coverages the amount of quartz cements is decreased as opposed to samples having smaller grain coating coverages. The samples from the Dutch K10 and K13 blocks generally contain smaller quartz cement volumes and the cor relation of less quartz cement with increasing grain coating coverages is not as pronounced as in the NE Hannover sample series. Only at grain coating coverages above $90 \%$ a decrease in quartz cement volumes is visible. Below $90 \%$ grain coating coverage the average quartz cement volume is $0.90 \%$, above $90 \%$ it is only $0.25 \%$.

The observed grain coating types in the studied reservoir sandstones include chlorite (Fig. 10 a), illite (Fig. 10 c), and pigmented hematite dust rims (Fig. 10 b, d). Samples from NE Hannover contain mainly chlorite and pigmented hematite grain coatings (Fig. $10 \mathrm{a}, \mathrm{b}$ ) and minor illite. In contrast, the samples from the Dutch K10 and K13 blocks contain mainly illite and some pigmented hematite dust rims (Fig. $10 \mathrm{c}$, d).

The observed textures include tangential and subtangential or radial textures for the clay minerals. In grain surface embayments, thicker portions of clay and hematite can be found.

\subsection{Grain coatings and depositional environment}

The grain coating coverage for the dune environment varies from $14 \%$ to $97 \%$. The range of grain coating coverages for dry sandflat environments is from $5 \%$ to $97 \%$. Damp sandflat deposits cover $23 \% 91 \%$, whereas wet sandflat deposits extend from $29 \%$ to $69 \%$. Fluvial deposits exhibit coverages from $19 \%$ to $83 \%$ and lake margin 


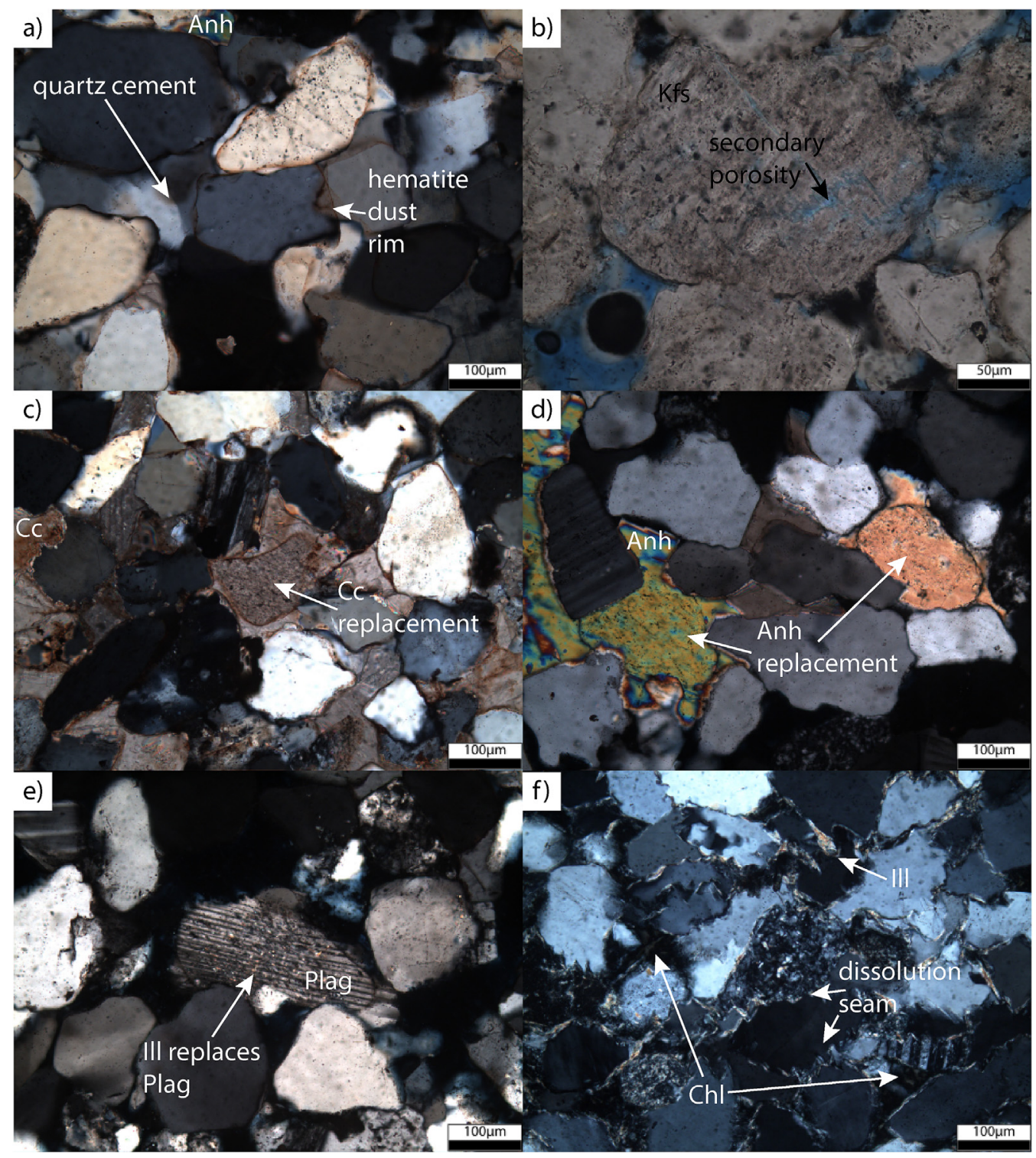

Fig. 6. a) Syntaxial quartz cement on detrital grains. Original grain outlines are marked by pigmented hematite dust rims (sample B4, $4561.6 \mathrm{~m}$ TVD). b) Secondary porosity of K-feldspar grain in sample B4 (4561.6 m TVD). c) Inter- and intragranular calcite (Cc) cement (sample B4, $4561.6 \mathrm{~m}$ TVD). d) Inter- and intragranular anhydride (Anh) cement in sample E10 (4350.9 m TVD). e) Illite (Ill) replaces detrital plagioclase grain in sample E10 (4350.9 m TVD). f) Illite (Ill) located at grain contacts and in dissolution seams at irregular grain contacts in sample C8 (4388.5 m TVD). Chlorite cements appear in intragranular pores. (For interpretation of the references to colour in this figure legend, the reader is referred to the Web version of this article.)

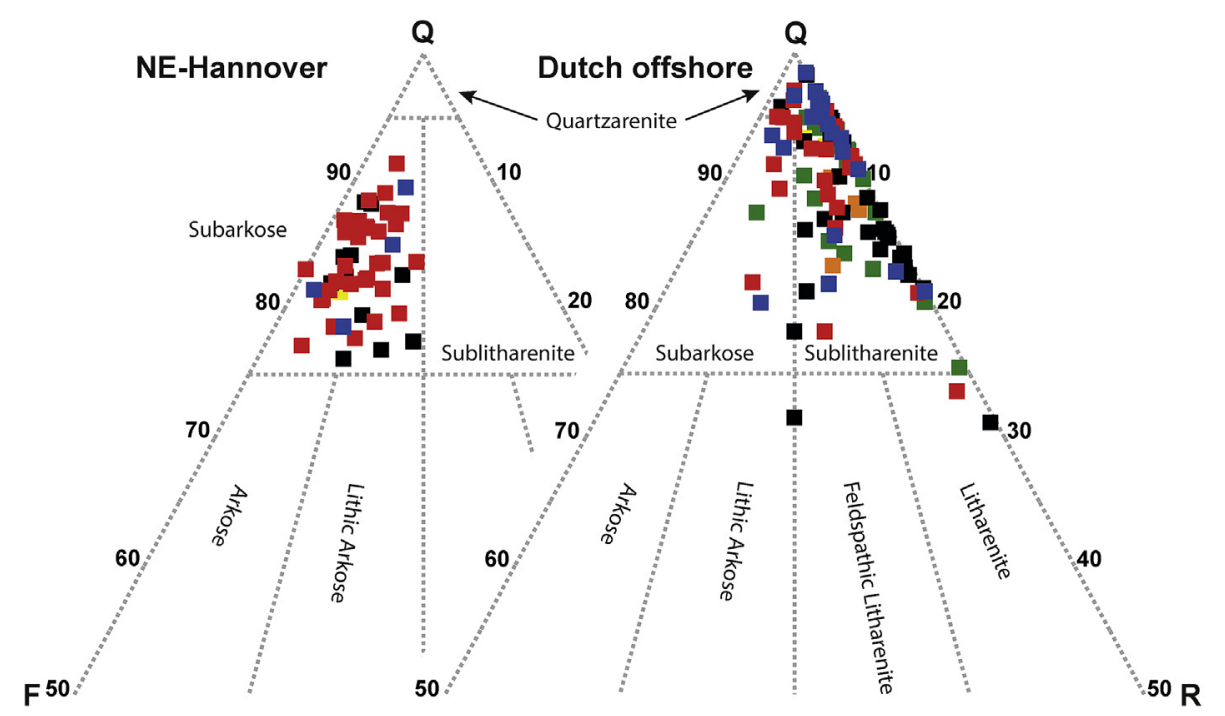

Fig. 7. QFL plots for the different study areas showing the detrital composition in regard to their depositional environments. No clear accumulations are visible across the Permian strata studied in this study. The QFL plots only show compositions above $50 \%$ quartz. a) Samples from NE-Hannover plot in the field of subarkoses. b) Samples from the Dutch offshore generally contain less feldspar and samples are classified as quartzarenites, subarkoses, sublitharenites, feldspathic litharenites and litharenites. (For interpretation of the references to colour in this figure legend, the reader is referred to the Web version of this article.)

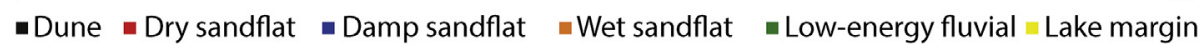




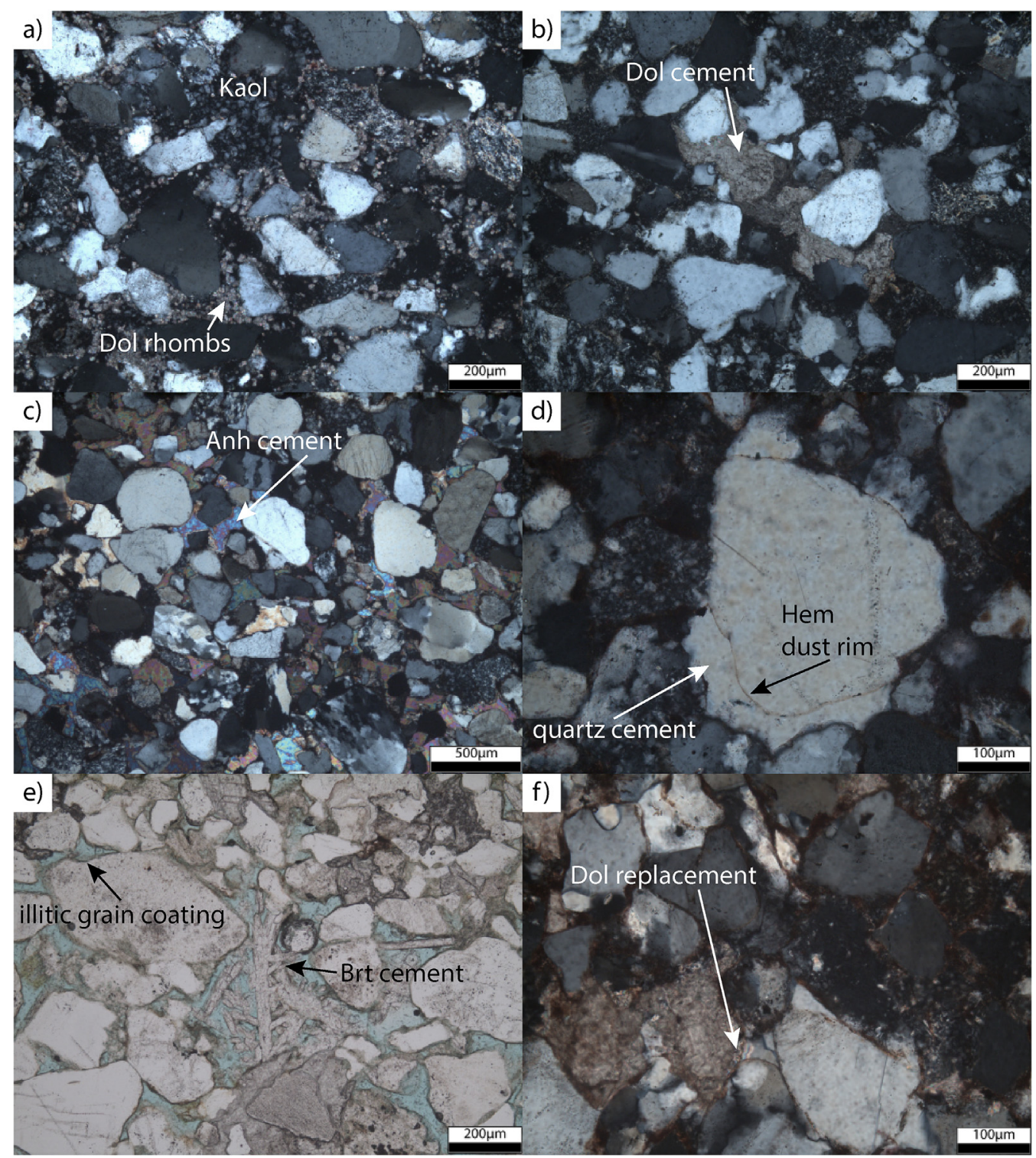

Fig. 8. a) Dispersed dolomite rhombs in the pore space of sample G1 of well G (2772.7 m TVD). Kaolinite occludes the pore space. b) Pore-filling and framework stabilising dolomite cement (H3, $3071.5 \mathrm{~m}$ TVD). c) Pore-filling anhydride cement in sample G25 (2831.2 m TVD). d) The detrital hematite dust rims outline the grain surface and allow the identification of syntaxial quartz overgrowth cements (G34, $2855.5 \mathrm{~m}$ TVD). e) Grain-coating illite and barite laths in sample I2 $(2899.2 \mathrm{~m}$ TVD). f) Dolomite cement in secondary pore in sample G10 (2786.5 m TVD). The mostly replaced grain is still marginally visible, showing low birefringence with light grey interference colours indicating remnants of K-feldspar. Dol: dolomite, Kaol: kaolinite, Brt: barite, Anh: anhydride, Hem: hematite. (For interpretation of the references to colour in this figure legend, the reader is referred to the Web version of this article.)

deposits cover $31 \% 65 \%$. A clear delineation is not possible with medians (lines in Box Whisker Plot, Fig. 11 a) and arithmetic means (small boxes in Box Whisker Plot, Fig. 11 a) which show little variation and not much separation. Additionally, damp and wet sandflat, as well as lake margin deposits are characterised by larger amounts of detrital clay in the pore space and as layers as opposed to samples from the other depositional environments. This impacts the evaluation of grain coating coverages and reduces available pore space for quartz ce mentation.

\subsubsection{Detrital grains and grain coatings}

The replacement of volcanic rock fragments by chlorite was re corded in samples from all wells in NE Hannover (Fig. 12). Chlorite and chlorite smectite grain coatings are also recorded from this area, but limited to wells A, C, and E (Fig. 13 a), while wells B and D contain mainly illite or pigmented hematite coatings (Fig. 13 b). Chlorite was identified by EDX spectra and by greyish interference colours in cross polarized lights (xpl) and a weak green colour in plane polarized light (ppl). In the studied samples, chlorite appears either tangential on grain surfaces (Fig. $13 \mathrm{c}$ ) or as small rosettes (Fig. $13 \mathrm{~d}$ ). Where present as a tangential grain coating, no smectite was detected by EDX. In contrast, chlorite rosettes are observed to grow on tangential smectitic coatings
(Fig. 13 d). The presence of chloritic grain coatings is thus not only related to samples containing altered volcanic rock fragments. The correlation of the presence and amount of volcanic rock fragments and presence of chlorite grain coatings thus yields no consistent result.

\subsubsection{Grain size and grain coatings}

Box whisker plots in dependence of grain size classes (Fig. 11 b) weakly suggest that samples consisting of finer grains have, on average (arithmetic mean, black boxes in Fig. 11 b), a larger grain coating coverage than samples consisting of coarser grains. However, the spread of observed coating coverages is large and grain size classes are unequally distributed.

On the scale of each sampling area, neither samples from NE Hannover reservoirs (Fig. $11 \mathrm{c}, \mathrm{R}^{2}=0.04$ ), nor the sample set from the Dutch offshore show a good correlation (Fig. $11 \mathrm{c}, \mathrm{R}^{2}=0.02$ ) of finer grain size versus better grain coating coverage. The additional color coding of depositional environment bears no consistent basis for addi tional correlations (Fig. $11 \mathrm{c}$ ).

\subsubsection{Sorting and grain coatings}

All samples from NE Hannover are moderately sorted, whereas samples from the Dutch K10 and K13 blocks range from very poorly 


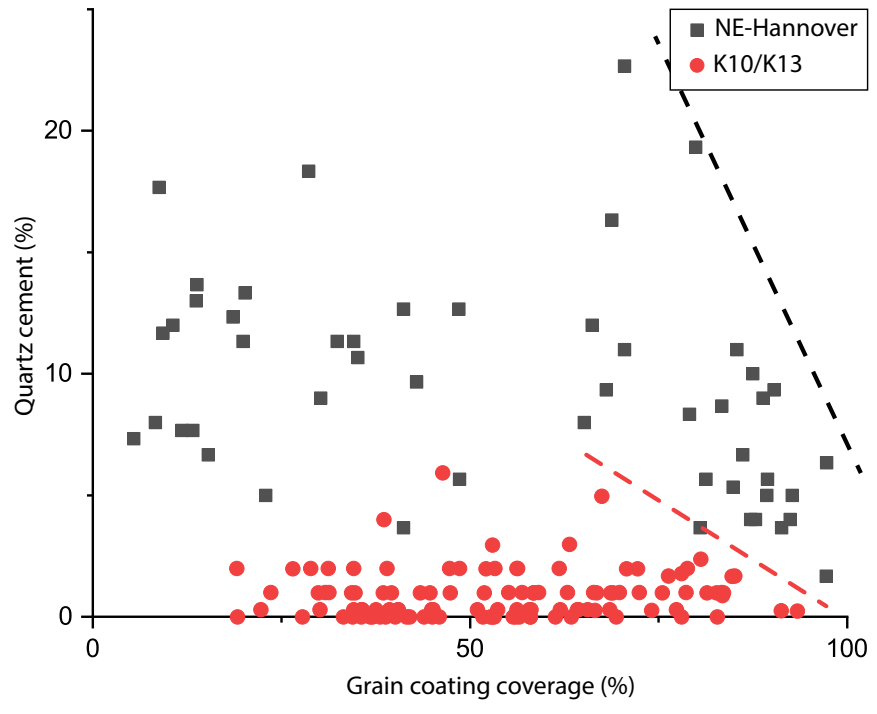

Fig. 9. Crossplot of grain coating coverage and quartz cement volumes. Above a grain coating coverage of $80 \%$ the inhibition effect is clearly visible in the NEHannover dataset (average quartz cement volume $<80 \%$ grain coating coverage: $11.23 \%$, average quartz cement volume $>80 \%$ grain coating coverage: $6.04 \%$ ) and above $90 \%$ for the Dutch Offshore sample series (average quartz cement volume $<90 \%$ grain coating coverage: $0.90 \%$, average quartz cement volume $>90 \%$ grain coating coverage: $0.25 \%$ ). (For interpretation of the references to colour in this figure legend, the reader is referred to the Web version of this article.)

sorted to very well sorted (Fig. $11 \mathrm{~d}$ ). Except for classes with less than 5 samples (very poorly and very well sorted), all sorting classes contain a range of grain coating coverages between $\sim 30$ and $80 \%$ (Fig. $11 \mathrm{~d}$ ).

Regardless of sorting, coating coverages consistently cover a range from poorly to well coated and do not concentrate within a certain sorting class (Fig. $11 \mathrm{~d}$ ). Comparing the different wells in the studied areas results in no consistent correlation of better or worse grain coated samples in dependence of sediment sorting. Median values (P50, hor izontal lines in Fig. 16) and averages (arithmetic mean, black boxes in Fig. 16) as statistical measures also do not show a correlation of grain coating coverages and sorting.

A regression analysis of grain coating coverage and sorting classes indicates a slight decrease in grain coating coverage, when sorting in creases. However, the coefficient of correlation $\left(\mathrm{R}^{2}\right)$ is very poor at only 0.002 . However, the range of grain coating coverage seem to correlate with the specific well (Fig. 11 e).

\subsection{Grain coatings and reservoir quality}

To visualize the impact of grain coatings on reservoir quality the grain coating coverage was plotted on a porosity permeability cross plot. In NE Hannover an increase in grain coating coverage generally corresponds to better porosity and higher permeabilities. Although the impact of quartz cements in NE Hannover seems to be inhibited by grain coating coverages above $80 \%$, other pore filling cements are un affected by this process. The total cement volumes additionally de crease the porosity and permeability of studied samples (Fig. 14 a). Samples from the Dutch offshore show high porosities and perme abilities and the general trend towards better reservoir quality at high grain coating coverages is not as pronounced (Fig. $14 \mathrm{~b}$ ). When it comes to total cement volumes, the correlation is also not as clear as in the NE Hannover data set.

Generally, the more deeply buried samples from NE Hannover show that grain coatings can affect reservoir quality in preserving porosity by inhibiting syntaxial quartz cements. In contrast, samples which have been buried to shallower depths, do not show a direct impact of grain coatings on reservoir properties.

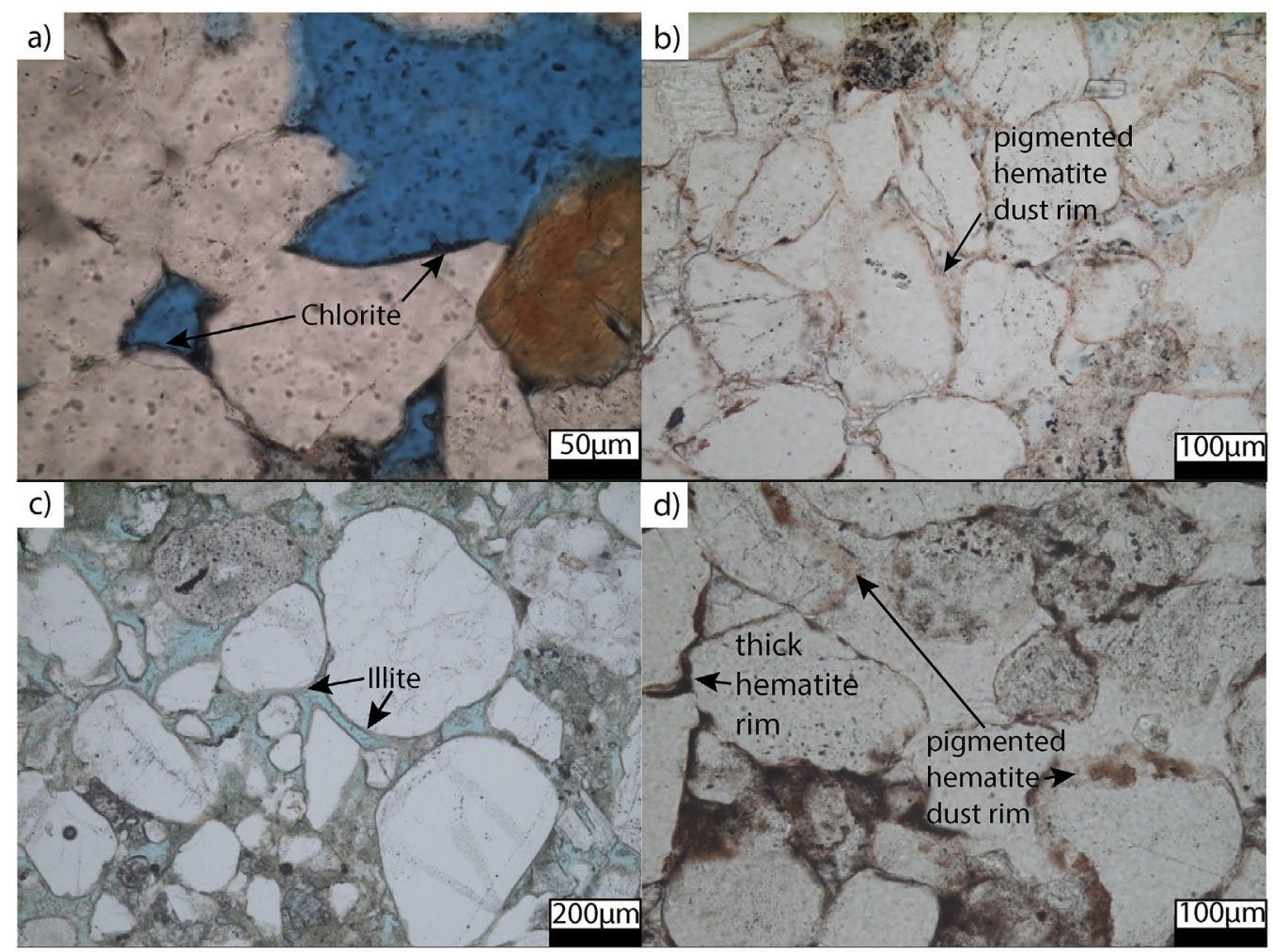

Fig. 10. Overview of observed grain coating types in studied samples. a) Chlorite grain coating in sample E10 (4350.9 m TVD, NE-Hannover). b) Pigmented hematite dust rim in sample B6 (4564.0 m TVD, NE-Hannover). c) Illite grain coatings in sample I1 (2894.8 m TVD, K10 block, Dutch offshore). d) Pigmented hematite rims in sample G $35(2857.9 \mathrm{~m}$ TVD, K10 block, Dutch offshore). (For interpretation of the references to colour in this figure legend, the reader is referred to the Web version of this article.) 

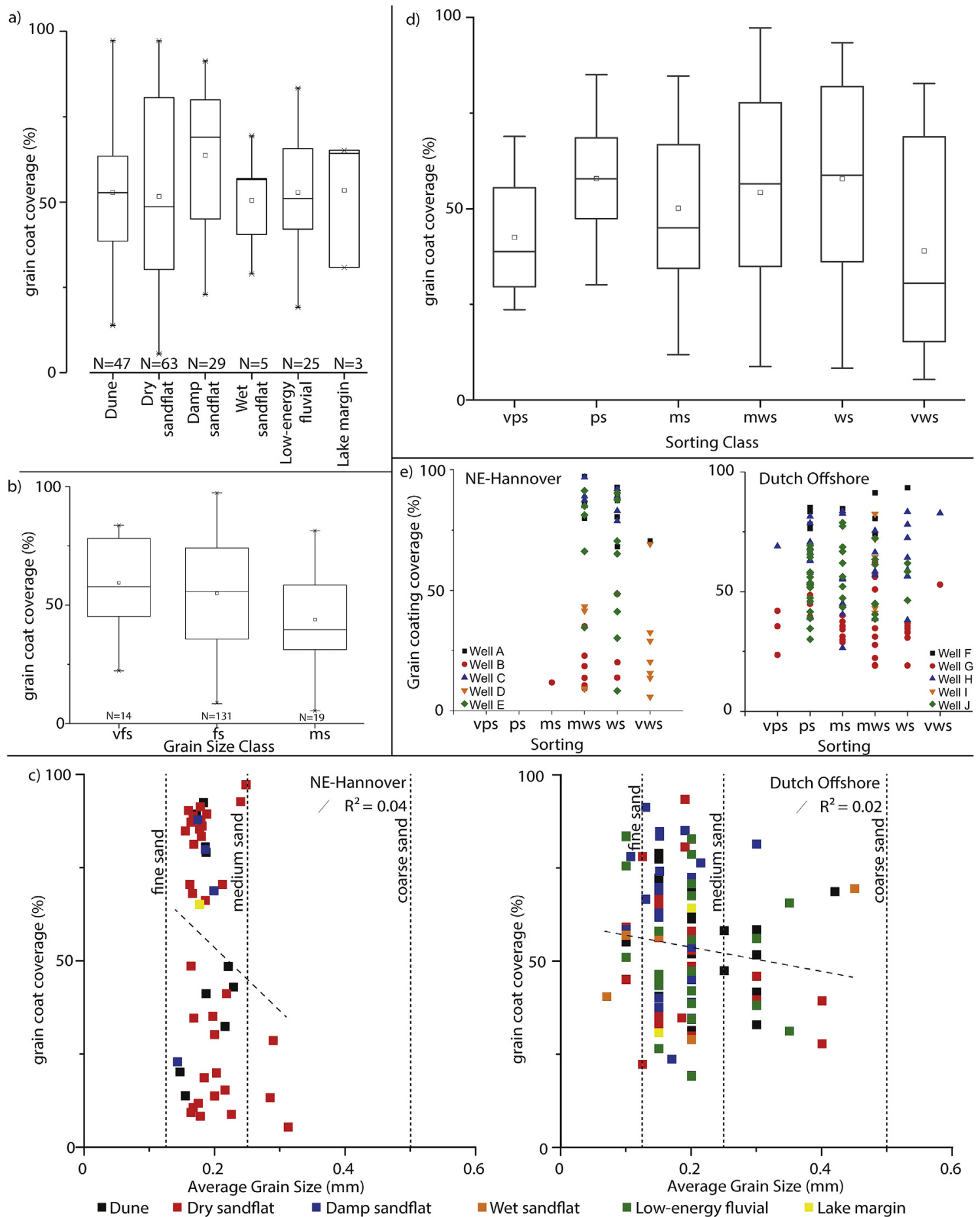

Fig. 11. a) Box-whisker plots of the coating coverages plotted for the studied depositional environments. The compilation highlights the spread of coating coverages. The median of the samples is given by the lines inside the box, the arithmetic mean is given by the boxes. Dashes at the top and bottom give the $0 \%$ and $100 \%$ data, $\mathrm{x}$ marks the $1 \%$ and $99 \%$ data points. b) Box-whisker plot of the distribution of observed grain coating coverages in the different grain size classes of medium (ms), fine (fs), and very fine grained sandstones (vfs). Although the arithmetic means and medians indicate a preference of higher coating coverages in finer grained sandstones, the spread of coverages is still largely overlapping. c) Correlation of coating coverage versus the average grain size in mm of samples from NE-Hannover and the Dutch offshore. The color code represents the depositional environments. Only a weak correlation between grain sizes and coating coverages can be deduced. d) Boxwhisker plot of the grain coating coverage for the different sorting classes. Medians and averages do not indicate a clear correlation of grain coating coverages with an increase or decrease in sorting. e) Cross-plot of sorting classes and grain coating coverage. All samples from NE-Hannover are moderately sorted, and a correlation cannot be established. The samples from the Dutch offshore cover a broad range of very poorly-to very well sorted sandstones. No correlation $\left(\mathrm{R}^{2}=0.002\right)$ can be deduced on a slight decrease in grain coating coverage with an increase in sorting. vps: very poorly sorted, ps: poorly sorted, ms: moderately sorted, mws: moderately well sorted, ws: well sorted, vws: very well sorted 


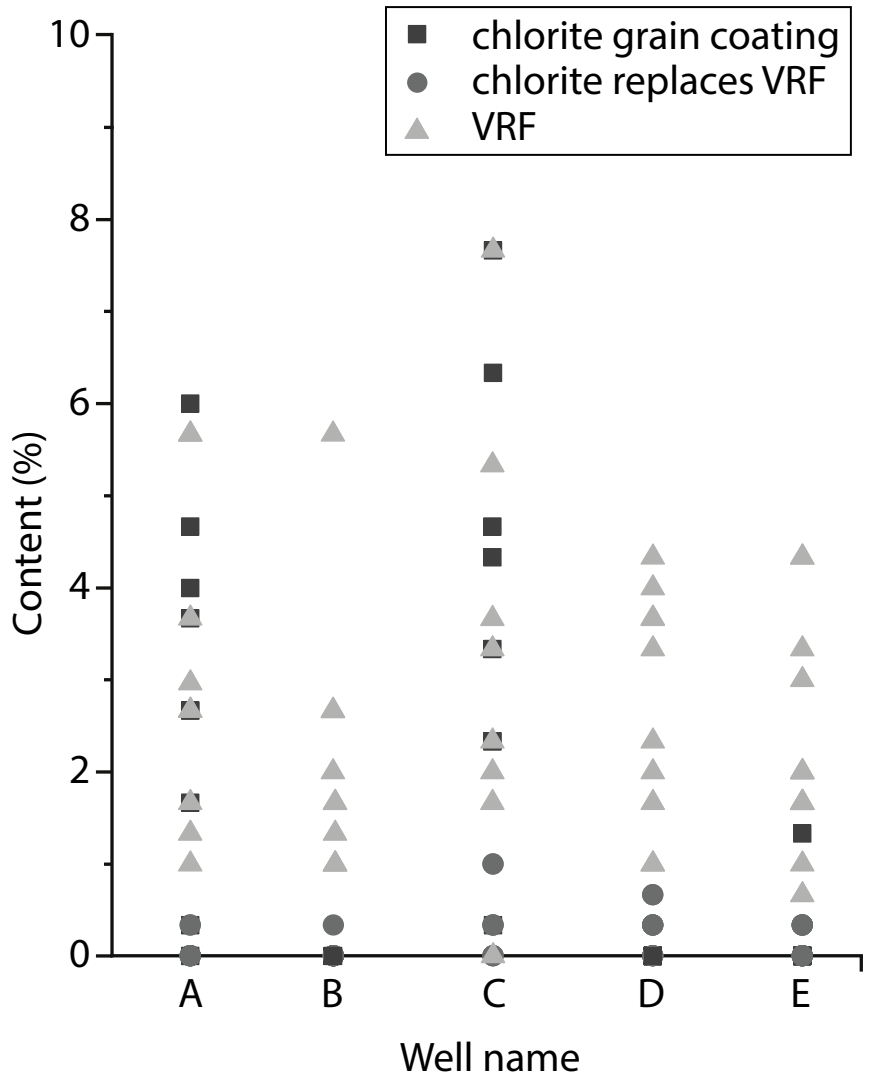

Fig. 12. Compilation of point-counted results of the volcanic rock fragments. All samples contain volcanic rock fragments in varying amounts. Samples from all wells contain the replacement of volcanic rock fragments by chlorite. However, only samples from wells A, C, and E contain chlorite grain coatings.

\section{Discussion}

\subsection{Diagenetic variations within a reservoir setting}

\subsubsection{NE Hannover - Bahnsen member}

In the samples from the wells NE of Hannover, earliest diagenetic alterations include the formation of pigmented hematite rims (Fig. 6 a), precursory clay mineral coatings (Fig. 6 f), K feldspar , calcite (Fig. 6 c), anhydrite (Fig. 6 d), baryte cementation and $\mathrm{K}$ feldspar dissolution (Fig. 6 b) (cf. Gaupp et al., 1993; Schöner and Gaupp, 2005). Deep burial diagenetic alteration is most prominently the formation of quartz overgrowth cements (Fig. 6 a), chlorite and illite authigenesis (Fig. 6 f), further phases of calcite and anhydride precipitation (Fig. 6 c, d, Fig. 15 a), and a late bitumen staining (cf. Schöner and Gaupp, 2005; Busch et al., 2018). Smectitic grain coatings on which chlorite rosettes grew indicate a precursory grain coating phase, which has been partially replaced by chlorite.

Within this area, the most pronounced difference between the au thigenic composition is the presence of chloritic grain coatings in three of five wells penetrating the same lithology in an area covering 10 by $6 \mathrm{~km}$. Generally, the rocks experienced closely aligned burial conditions (Fig. 3). Temperature anomalies in association with salt pillows (well C) are only locally restricted and cannot be used to explain the differences in reservoir qualities, or authigenic mineral assemblages (Busch et al., 2018). The alteration of precursory grain coating clay minerals to chlorite may be related to the initially grain coated surface area of quartz grains. Where tangential grain coatings were incomplete, pre cursory grain coatings could be overgrown and are present as illite. More complete tangential precursory grain coating coverages inhibited quartz overgrowth and in that case, alteration to chlorite could occur during burial diagenesis (e.g. Ajdukiewicz et al., 2010).

In an alternative model for the localized chlorite formation, fluid migration along fault was reported as underlying process (e.g. Gaupp et al., 1993; Wüstefeld et al., 2017). In our study area, however, fluid migration along fault planes, based on the interpretation of faults from seismics is an insufficient explanation for differences in the authigenic mineral assemblage since proximities to faults and fault intersections are comparable for all wells.

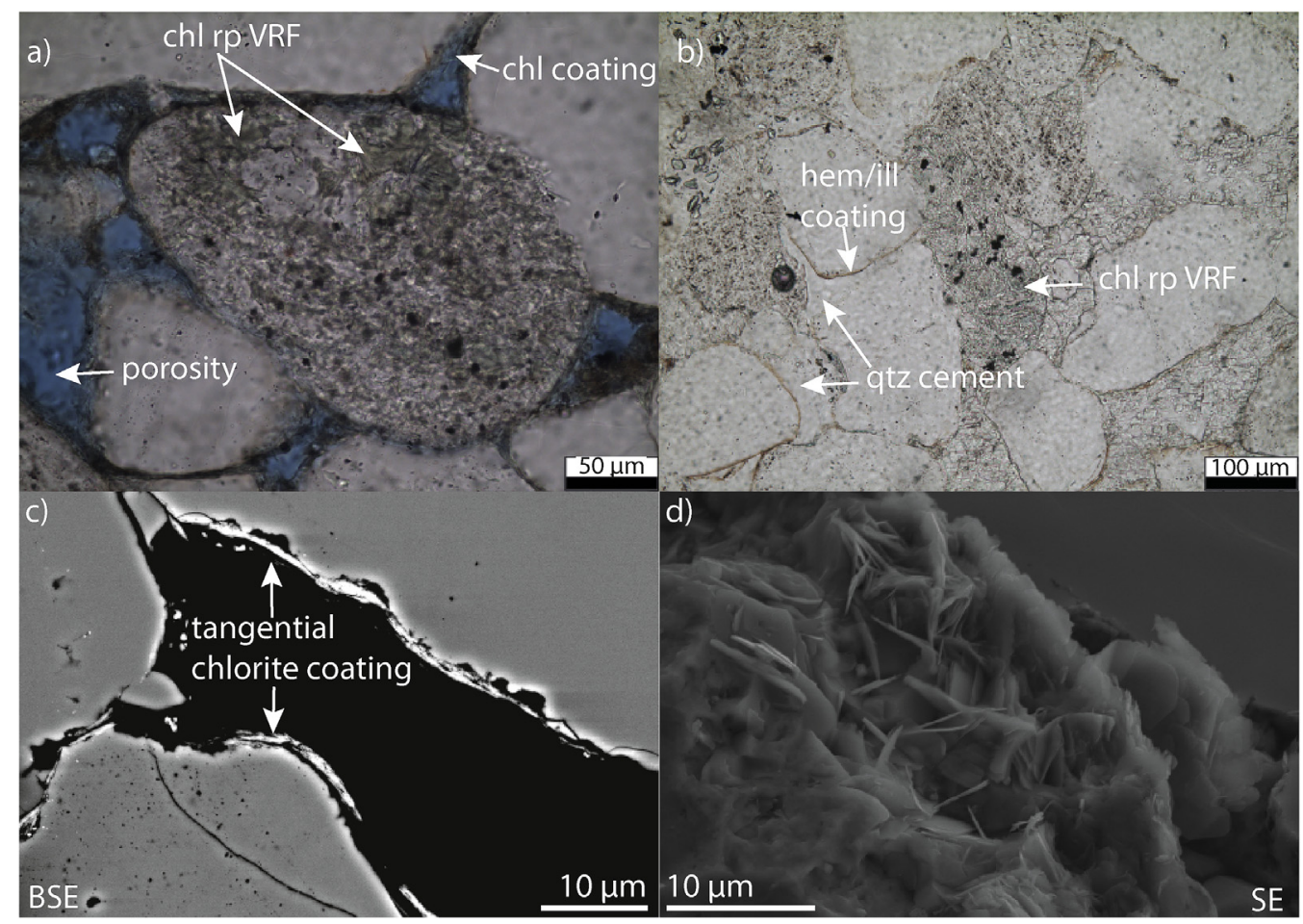

Fig. 13. a) Chlorite replaces volcanic rock fragments in sample from well A (A9, $4271.41 \mathrm{~m}$ TVD). The sample is mainly characterised by chlorite coatings. b) Chlorite (chl) replaces plagioclase-rich volcanic rock fragment (VRF) in sample from well D (D6, $4513.7 \mathrm{~m}$ TVD). The coatings in this sample consist of hematite (hem) pigments and minor amounts of illite (ill). c) Scanning electron microscope images of different chlorite coating morphologies in samples from Well E. Tangential chlorite coating in back scattered electron image (BSE), possibly replacing an early smectite precursor (Sample E10, $4350.9 \mathrm{~m}$ TVD). d) Chlorite rosettes growing on top of a smectite precursor in secondary electron image (SE) (block sample of sample E11, $4351.6 \mathrm{~m}$ TVD). 

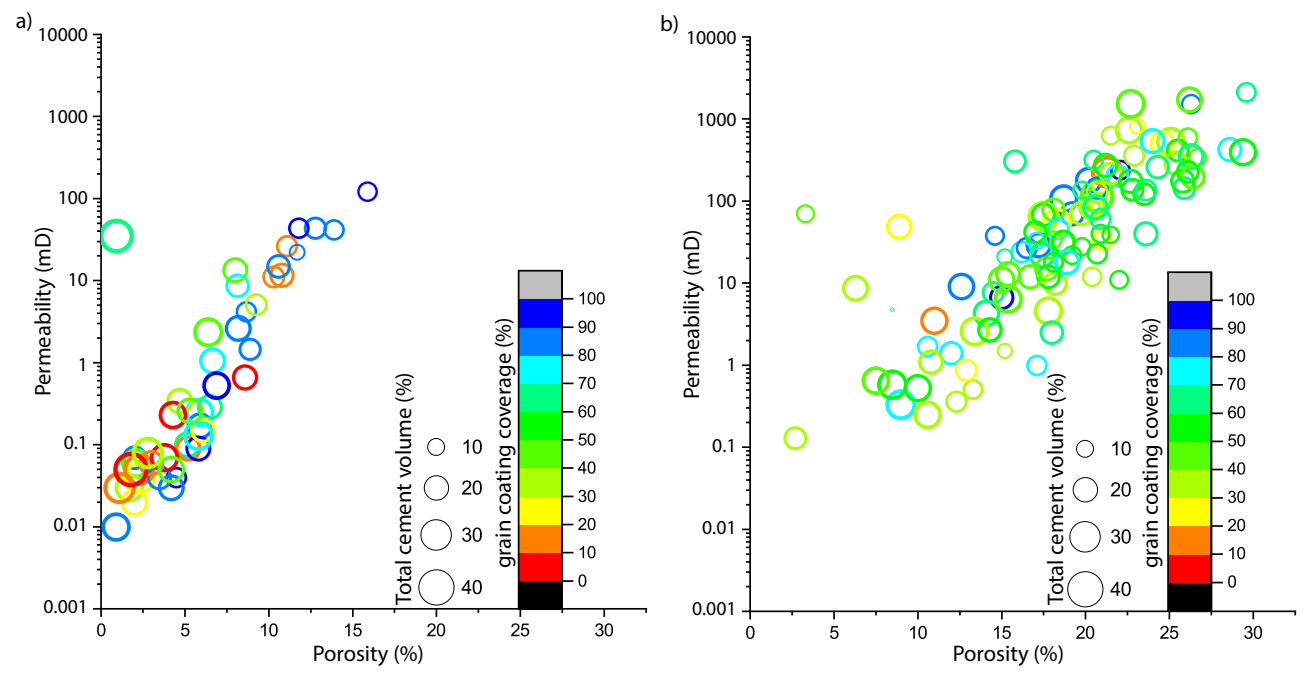

Fig. 14. Porosity-permeability cross-plot of a) NE-Hannover and b) Dutch offshore datasets. The color-code corresponds to the grain coating coverage (in percent, red corresponds to poor grain coating coverage, blue corresponds to good grain coating coverage) and circle area corresponds to the total cement volume. a) In NE-Hannover an increase in grain coating coverage generally corresponds to better porosity and higher permeabilities. The low porosity and permeability samples are also characterised by highest total cement volumes. b) Samples from the Dutch offshore have generally higher grain coating coverages. The effect of total cement volumes on porosity and permeability is not as pronounced as in NEHannover. (For interpretation of the references to colour in this figure legend, the reader is referred to the Web version of this article.)

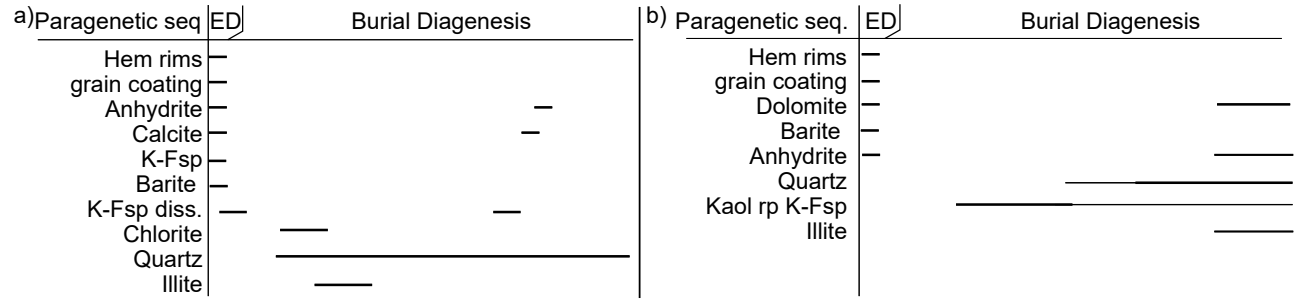

Fig. 15. Paragenetic sequences of the studied areas, based on petrographic examination. a) NE-Hannover. b) Slochteren Sandstone Formation. Hem: hematite, KFsp: K-feldspar, Kaol: kaolinite.

\subsubsection{Dutch offshore Slochteren Sandstone}

In Rotliegend sandstones from the Dutch offshore wells, grain coatings mainly consist of tangential or radial illite or pigmented he matite dust rims (Fig. $4 \mathrm{c}$, d). The predominant grain coating mineral phase is not restricted to certain wells in contrast to the observations from NE Hannover. Early diagenetic alterations include pigmented hematite dust rims (Fig. $8 \mathrm{~d}$ ), precursory clay mineral coatings, dolo mite (Fig. 8 a, b, f), baryte (Fig. 8 e), and anhydride cements (Fig. 8 c) (Gaupp and Okkerman, 2011; Molenaar and Felder, 2018). Burial di agenesis is represented by the alteration of $\mathrm{K}$ feldspar to kaolinite (Fig. 8 a), quartz cementation (Fig. 8 d), illite authigenesis (Fig. 8 e), a late dolomite cement precipitation, and a late anhydride phase pre cipitation (Fig. 15 b) and hydrocarbon charge (Gaupp and Okkerman, 2011; Molenaar and Felder, 2018).

The samples of both K10 and K13 blocks are comparable in terms of lithotypes and diagenetic assemblages (Fig. 7, Table 3). The most pro nounced difference is the amount of feldspar grains at present. Some samples which have been subject to only relatively shallow burial, contain remnants of feldspar grains, whereas in other samples, they have been completely dissolved. The authigenic compositions of all samples are comparable. The radial grain coating illite is interpreted in similar settings to be a product of burial diagenesis and are not ne cessarily related to a detrital precursor (Zwingmann et al., 1998; Clauer et al., 2012). This supports an independence of grain coating formation from the depositional environment. In contrast, most of the tangential illitic grain coatings can be interpreted as replacements of precursory tangential, possibly smectitic, grain coatings (Ajdukiewicz et al., 2010).

The alteration of kaolinite to illite is largely reliant on the potassium from $\mathrm{K}$ feldspar alteration and temperature or an external potassium source (Lanson et al., 2002). Lower temperatures and less available potassium are interpreted to be inhibiting the reaction from kaolinite to illite, favouring kaolinite (Lanson et al., 2002). Alternatively, a decrease in the $\mathrm{K}^{+} / \mathrm{H}^{+}$ratio, indicating more acidic conditions, favors the for mation and preservation of kaolinite rather than further alteration to illite (e.g. Ehrenberg, 1991; Gaupp et al., 1993; Van Keer et al., 1998).
5.1.3. Main diagenetic differences between NE Hannover and the Dutch offshore

The depositional environments of both study areas are comparable. The provenances differ slightly from different parts of the Variscan mountain belt (Katzung, 1975; Lutz et al., 1975; George and Berry, 1994; Verweij, 2003), mainly resulting in dissimilarities in the assem blage of rock fragments. Samples of both areas have been subject to different burial depths, resulting in a different thermal exposure (Fig. 3). All sampled settings have been subject to temperatures above $80^{\circ} \mathrm{C}$ and the illitization and chloritization of possible precursor phases, smectite and kaolinite, are expected to have started.

The most pronounced difference of both areas is the kaolinite ce ment content. The alteration of detrital feldspar grains to kaolinite is pervasive in Dutch samples (Fig. 8 a, Tab. 3). The alteration of this kaolinite to illite has ceased in absence of an additional potassium source, once the $\mathrm{K}$ feldspar was consumed in most of the samples (Fig. 7, Tab. 3). In samples from NE Hannover, the formation of illite via the alteration of feldspar to kaolinite and illitization of kaolinite in presence of a potassium source (here $\mathrm{K}$ feldspar), is pervasive and all kaolinite is interpreted to have been consumed during this reaction (Tab. 3) (Lanson et al., 2002).

\subsection{Grain coatings}

\subsubsection{Depositional environment and grain coatings}

The studied depositional environments of Rotliegend sandstones from two areas in the Southern Permian Basin do not correlate with the coverage of detrital grains by coatings (Fig. 11 a). However, multiple dependencies of reservoir properties on the depositional environments are evident from literature (Ramm, 2000; Elias et al., 2004; Khalifa and Morad, 2015; Marchand et al., 2015; Wooldridge et al., 2019b). Al though the arithmetic means of the data show a slight separation be tween depositional environments and grain coating coverage (solid black boxes in Fig. 11 a), they will result in incorrect associations since only the extremes ( $>80 \%$ or $90 \%$ grain coating coverage) are 
responsible for positive reservoir quality anomalies in the presented deeply buried cases.

No consistent dependencies can be established, most likely due to differences in the source areas, in climate, water availability and the following diagenetic pathway. Climatic changes do seem to exert a major control on the early authigenic development of these sandstones, regardless of depositional environment, also including pore occluding carbonate and sulfate cementation (Ajdukiewicz et al., 2010). Varia tions of detrital compositions might additionally impact the later di agenetic alteration (Bahlis and De Ros, 2013). However, a correlation of grain coating coverages to certain depositional environments of a si milar stratigraphy as opposed to another depositional environment can clearly be discarded for the studied fluvio aeolian Rotliegend samples. This highlights the need for area and sample specific analysis for re servoir quality assessment. Variations may even become apparent within one reservoir unit as shown by the Bahnsen sandstone member samples from NE Hannover, where 3 of 5 wells, all located in the same graben setting contain chloritic grain coatings and the other two wells completely lack chloritic grain coatings.

\subsubsection{Detrital grains and grain coatings}

Significant differences in detrital composition are related to the different source areas and subsequent diagenetic alteration (Fig. 4). However, the presence of rock fragments, especially of volcanic rock fragments, can influence the development of grain coatings on detrital grains, i.e. chlorite rims (Anjos et al., 2000; Anjos et al., 2003; Bahlis and De Ros, 2013).

In the sample series from NE Hannover, no link between the al teration of volcanic rock fragments and grain coating coverages can be identified. The five wells with similar contents of volcanic rock frag ment alteration exhibit strong variations in grain coating coverages and presence of grain coating chlorite. Alterations of volcanic rock frag ments towards chlorite are observed in samples from all wells in the NE Hannover area (see Figs. 12 and 13). The presence of chloritic coatings in samples from wells A, C, and E and their absence in samples from well $\mathrm{B}$ and $\mathrm{D}$, only containing minor illite and hematite, can be ex plained by the incomplete coating coverage of precursory grain coat ings. The incomplete coatings are readily overgrown by quartz cement thus isolating the precursory and incomplete grain coatings and grain surfaces in wells B and D from further alteration and mineral growth. The overgrown coatings are isolated from the pore volume and no available cations are further incorporated during mineral transforma tion from smectite to chlorite.

The alteration of smectite to chlorite is also reported to favour the authigenic replacement by chlorite as a grain rim in presence of altered volcanic rock fragments (Bahlis and De Ros, 2013). Where the pre cursory coating coverage is larger, pervasive quartz cementation is in hibited (Anjos et al., 2003). Thus, the direct exposure of precursory coating phases to the connected pore volume allow the alteration to chlorite in the presence of cations, which are released into solution by the alteration of volcanic rock fragments. This process could explain the observed differences in coating mineralogy (chlorite vs. illite) and grain coating coverage from wells A E.

Smectite as a substrate for chlorite growth is interpreted from EDX spectra. The direct alteration of volcanic rock fragments towards chlorite grain coatings during early diagenesis (Bahlis and De Ros, 2013) can be disregarded for samples from NE Hannover, otherwise they should be present in all samples with a similar burial history (Fig. 3). The diagenetic alteration could either be related to a precursor grain coating clay cement which is present in some parts of the li thology. Indications for the presence of smectitic grain coatings inter grown with chlorite grain coatings are present. Alternatively, the di agenetic system could be regarded as a system locally driven by structural anisotropies (e.g. Gaupp et al., 1993). However, the role of smectitic grain coatings as cation donors during chlorite authigenesis and smectite replacement should be considered.
The presented variability in detrital composition is strongly related to the location and subsequent diagenetic alteration of the studied samples. Samples from NE Hannover are rich in feldspar and contain some lithic fragments, while Dutch samples are poor in feldspar, mainly related to grain dissolution and alteration to kaolinite. These differ ences have an impact on diagenesis, especially considering an internal potassium source for the illitization of kaolinite (Lanson et al., 2002).

\subsubsection{Grain size and sorting}

In the studied dataset, regression analysis indicates no impact of the grain size on the grain coating coverage $\left(R^{2}=0.04\right.$ and 0.02$)$. With regard to the arithmetic mean, it seems that the finer the grains, the better the grain coating coverages (Fig. $11 \mathrm{c}$ ). However, due to the large scatter of data, and the very poor coefficients of correlation $\left(\mathrm{R}^{2}=0.04\right.$ and 0.02 ), this correlation is less reliable. Opposing to the observations where finer grain sizes contain larger grain coating coverages, theore tically the amount of material required to create complete grain coat ings is less in coarser grained sands and sandstones due to the smaller surface area per volume (Bloch et al., 2002). A clearer correlation, as could be established in aeolian dunes and marine shelf settings (Wilson, 1992), in estuarine sands (Wooldridge et al., 2017), or Permian Car boniferous Unayzah sandstones, Saudi Arabia (Shammari et al., 2011) could not be established (Fig. $11 \mathrm{c}$ ). The grain size does not seem to consistently impact the grain coating coverages in the Rotliegend study areas.

Additionally, a process governed by the grain size might be the abrasion of emplaced precursory clay phases. Finer grains are discussed to show less abraded grain coatings as opposed to coarser grains (Ajdukiewicz et al., 2010). Abrasion would additionally leave remnants of grain coatings in indentations in larger grains. This process is held responsible for observed differences of grain coating coverage in la minated wind ripple sands (Ajdukiewicz et al., 2010).

Universal trends cannot be delineated since most of the sorting classes cover a broad range of observed grain coating coverages and no separation is visible. Samples from NE Hannover only classify as moderately sorted sandstones. However, they cover the complete range of poorly to well grain coated. This additionally indicates the in dependence of grain coating emplacement and sorting in this sample series.

\subsubsection{Grain coatings and diagenesis}

Grain coatings are present in both settings. However, grain coatings in NE Hannover consist mainly of chlorite or smectite chlorite mixed layer clays and some minor illite (Fig. 16). Meanwhile illite is the dominant grain coating clay mineral in the Dutch samples (Fig. 16). The main controlling difference is the alteration of smectitic precursor clays to either chlorite or illite during burial diagenesis in the NE Hannover fields and the local growth of radial illite with and without a tangential precursor in fields in the Dutch fields. The diagenetic formation of clay minerals can thus form effective grain coatings (e.g. Platt, 1993), in hibiting or reducing syntaxial quartz cement growth, but are not con trolled by the depositional environment or any other sedimentary property in the presented cases. Studies on Rotliegend hosted illite textures in relation to their radiometric ages have been reported from Germany, showing that radial illites mostly post date the re crystallization of tangential illite (Liewig and Clauer, 2000; Havenith, 2012). If this authigenic growth predates the onset of syntaxial quartz cementation, as is indicated by the petrographic observations and the absence of quartz cement on very well coated grains, the clay mineral grain coatings of radial illite are efficient syntaxial quartz cement in hibitors, completely independent of the precursory grain coatings. Additionally, thick portions of hematite and clay minerals in grain surface embayments, are evidence for inherited grain coating materials and may in the case of hematite, not be viable as substrates for later tangential growth, although they can contain considerable amounts on interstitial clay (Hasner, 2004). However, the effect of thick hematite 


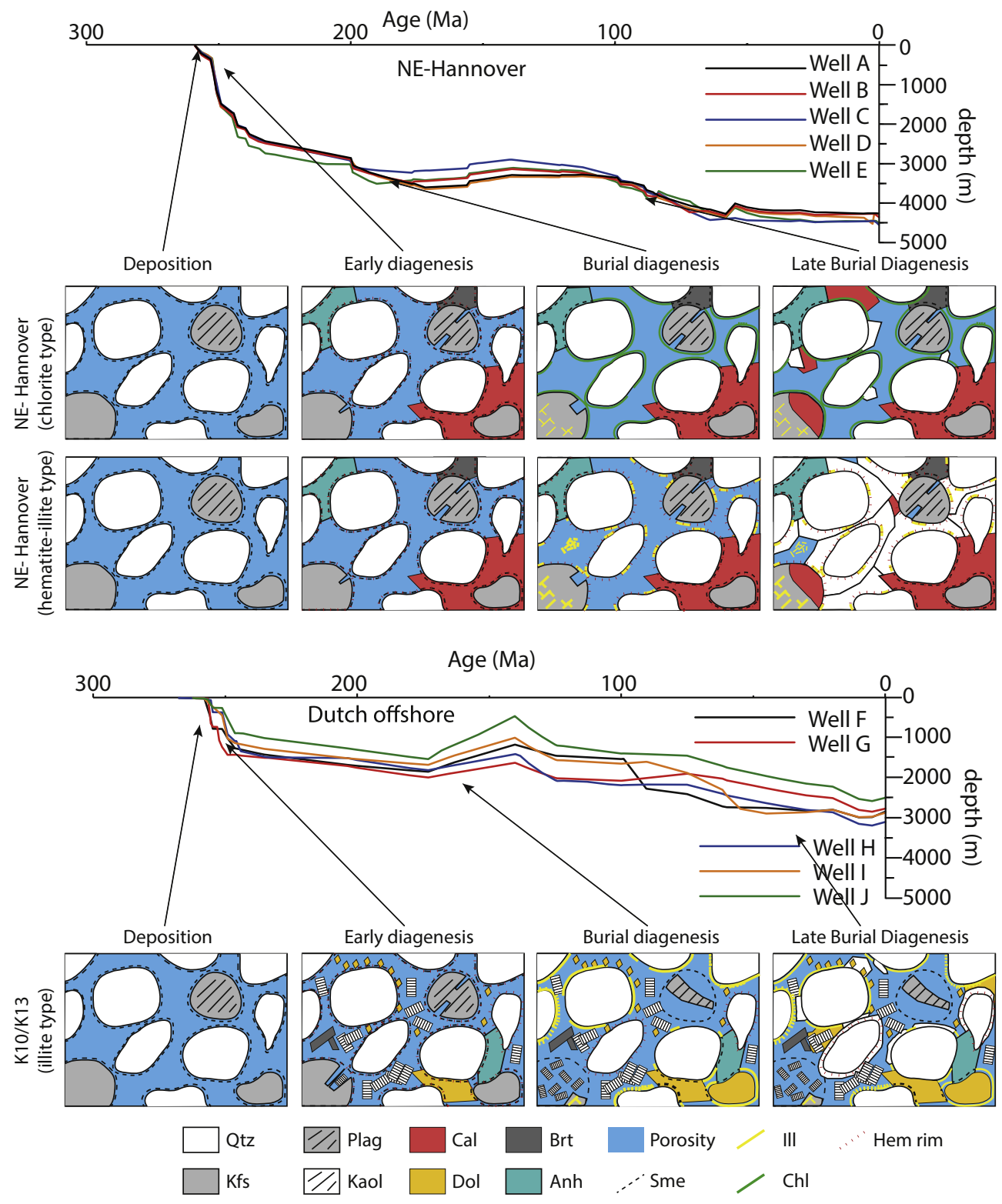

Fig. 16. Sketch of the main diagenetic processes affecting reservoir quality of the two studied settings. a, b) The samples from NEHannover have a similar detrital composition and are all affected by early carbonate and anhydride cementation, and to a minor degree barite and gypsum. Samples contain either chloritic grain coatings or illitic-hematitic grain coatings. Chloritic grain coatings are more well developed and can inhibit syntaxial overgrowth cementation when completely covering the grains. Samples containing mainly pigmented hematite rims and illitic grain coatings, develop less continuous grain coatings and are readily overgrown by syntaxial quartz cements. Secondary intragranular porosity is mainly created in feldspars or rock fragments, and often filled by late diagenetic carbonate phases and illite. The thermal exposure of these samples is quite comparable when comparing the burial curves, and the main difference in reservoir quality can be related to a more complete grain coating coverage of chloritic grain coatings. c) Samples from the Dutch offshore also show a similar detrital composition and early diagenetic alteration. Mainly early kaolinite, dolomite, and barite cementation is occurring, to some degree also anhydride. The precursory grain coatings are transformed to incomplete tangential illitic grain coatings, while tangential illite grows both on top on tangential substrates and on uncoated grain surfaces. Where samples are containing pigmented hematite rims, these are readily overgrown in late burial diagenesis. Secondary intragranular porosity is mainly filled by dolomite and kaolinite. Due to a lower thermal exposure as opposed to the NE-Hannover samples, the amounts of quartz cement are lower. The nearly complete dissolution of all feldspar grains reduces an initial source of potassium that could explain the presence of kaolinite, whilst temperatures were high enough to facilitate kaolinite to illite transformations. Qtz: Quartz, Kfs: K-feldspar, Plag: plagioclase, Kaol: kaolinite, Cal: calcite, Dol: dolomite, Brt: barite, Anh: anhydride, Sme: smectite, Ill: illite, Chl: chlorite, Hem: hematite. (For interpretation of the references to colour in this figure legend, the reader is referred to the Web version of this article.)

rims on the inhibition of syntaxial quartz cements is still given.

\subsection{Implications for reservoir quality modelling and prediction}

The direct correlation or application of processes acting on a sedi ment during deposition and its present day conditions as a buried and diagenetically altered sandstone is not directly possible for the studied Rotliegend sandstones.

The alteration of sandstones deposited in a similar setting in $\mathrm{NE}$ Hannover can result in a reservoir sandstone with very well developed chloritic grain coatings and a poorer reservoir sandstone with only hematitic dust rims (Figs. 6, 10 and 16). The chloritic grain coatings inhibit most of the quartz cementation, whereas the hematite dust rims are readily overgrown (Fig. 10 b, d, 16). Similarly, tangential and radial illite inhibit quartz cementation and improve reservoir quality in the Dutch offshore fields, whereas pigmented hematite dust rims are readily overgrown by syntaxial quartz overgrowth cements.

The differences in the authigenic assemblage, controlled by dif ferent burial scenarios and provenances of NE Hannover versus the
Dutch offshore Rotliegend reservoirs, indicate the importance of a de tailed local diagenetic study to assess the grain coating coverage. Especially feldspars can be considered as important factors in the au thigenesis of clay minerals (Lanson et al., 2002; Worden and Morad, 2002). While samples from the Dutch offshore are characterised by a large amount of kaolinite cements and small amounts of feldspars, the samples from NE Hannover completely lack kaolinite and contain more feldspar at present day (Fig. 16). While the kaolinite to illite alteration starts around $70{ }^{\circ} \mathrm{C}$ and is most pervasive from $130{ }^{\circ} \mathrm{C}$ (Worden and Burley, 2003), the alteration of feldspar to kaolinite is most pronounced in an early diagenetic realm with influx of meteoric waters (Worden and Morad, 2002). The differences in thermal exposure, the time spent at elevated temperatures, between the two areas favours the alteration of kaolinite to illite in samples from NE Hannover, while the alteration of $\mathrm{K}$ feldspar to kaolinite is favoured in samples from the Dutch offshore (Fig. 16). The differing degrees of alteration need to be considered when assessing reservoir quality controls, and no simple straight for ward correlation of sedimentary processes and grain coating char acteristics is possible in this study. 
The results of this study may have implication for reservoir geolo gists and diagenetic modelling approaches in the presented areas and elsewhere, implying that sample specific analyses or a very well un derstood regional diagenetic framework are required for accurate pre diction of reservoir quality in the subsurface.

\section{Conclusions}

Grain coating coverage cannot be directly linked to the depositional environment, sorting, or presence of detrital volcanic grains for Rotliegend sandstones in this study. Even on a small (km or interwell) reservoir scale no universally applicable controls can be observed. A direct application of these proxies for other nearby Rotliegend re servoirs for reservoir quality modelling and pre drill assessment is thus not directly possible. These findings might also be applicable to other settings.

The overall poor correlation of grain size and grain coating coverage and the large data scatter do not allow the use of these parameters as a universal indicator for the Rotliegend. Hence, no universal de pendencies can be derived for grain coating coverages.

The dependencies of grain coatings vary between the two areas, due to the varying superposition effect by other controlling processes and later diagenetic overprint. On a reservoir setting scale, the better grain coating coverage by precursory smectitic coatings favours the alteration to chlorite in NE Hannover samples. In the Dutch samples, growth of fibrous, radial illite is related to burial diagenetic reactions of kaolinite and potassium consuming all available feldspar. This investigation strongly confirms that the emplacement of precursory grain coatings is important, yet not the only control on effective grain coatings at depth. A complex interaction of several parameters, e.g. clay mineral avail ability during deposition as precursory/detrital clay coatings, infiltra tion of meteoric waters, pedogenetic processes, diagenetic growth of clay minerals (including formation water chemistry favouring different minerals to grow), microbial/biological interactions with sediments, grain sizes, sediment mobility/stabilization, source areas for detrital materials or inherited rims, early cementation, and diagenetic altera tions needs to be taken into account.

Reservoir quality for deeply buried sandstones in the present case is best when chlorite and illite coating coverage is high. Sandstones ex periencing less thermal exposure can be good reservoirs, regardless of the grain coating coverage. However, data lack a clear correlation be tween depositional environment, grain sizes, and sorting with the grain coating coverage. Thus, even in single reservoirs, cores must be in dividually considered for reservoir quality assessment and modelling.

\section{Acknowledgements}

BB and CH kindly acknowledge research funding by Wintershall Dea $\mathrm{GmbH}$. Discussions with N. Schleifer on petrophysical measurements as well as assistance by F. Kluin are thankfully acknowledged. Constructive comments by R. Gaupp, two anonymous reviewers, and Associate Editor H. M. Schulz are thankfully acknowledged.

\section{References}

Aagaard, P., Jahren, J.S., Harstad, A.O., Nilsen, O., Ramm, M., 2000. Formation of graincoating chlorite in sandstones. Laboratory synthesized vs. natural occurrences. Clay Miner. 35, 261-269. https://doi.org/10.1180/000985500546639.

Ajdukiewicz, J.M., Kronmüller, K., Dulce, C., Yip, G., 2014. Integrating early and late diagenesis models for spatial prediction of reservoir quality in deeply-buried eolian sandstones (abs.). In: AAPG International Conference \& Exhibition, Istanbul.

Ajdukiewicz, J.M., Larese, R.E., 2012. How clay grain coats inhibit quartz cement and preserve porosity in deeply buried sandstones: observations and experiments. AAPG Bull. 96 (11), 2091-2119. https://doi.org/10.1306/02211211075.

Ajdukiewicz, J.M., Nicholson, P.H., Esch, W.L., 2010. Prediction of deep reservoir quality using early diagenetic process models in the Jurassic Norphlet Formation, Gulf of Mexico. AAPG Bull. 94, 1189-1227. https://doi.org/10.1306/04211009152.

Amthor, J.E., Okkerman, J., 1998. Influence of early diagenesis on reservoir quality of Rotliegende sandstones, Northern Netherlands. AAPG Bull. 82 (12), 2246-2265. https://doi.org/10.1306/00AA7F04-1730-11D7-8645000102C1865D.

Anderson, R.S., 1988. The pattern of grainfall deposition in the lee of aeolian dunes. Sedimentology 35, 175-188. https://doi.org/10.1111/j.1365-3091.1988.tb00943.x.

Anjos, S.M.C., De Ros, L.F., Schiffer de Souza, R., Silva, C.M.A., Sombra, C.L., 2000 Depositional and diagenetic controls on the reservoir quality of Lower Cretaceous Pendência sandstones, Potiguar rift basin, Brazil. AAPG Bull. 84 (11), 1719-1742. https://doi.org/10.1306/8626C375-173B-11D7-8645000102C1865D.

Anjos, S.M.C., De Ros, L.F., Silva, C.M.A., 2003. Chlorite authigenesis and porosity preservation in the Upper Cretaceous marine sandstones of the Santos Basin, offshore eastern Brazil. In: Worden, R.H., Morad, S. (Eds.), Clay Mineral Cements in Sandstones. Blackwell Science Ltd., Oxford.

Antrett, P., 2011. Characterization of an Upper Permian Tight Gas Reservoir - A multidisciplinary, multiscale analysis from the Rotliegend, Northern Germany, Fakultät für Georessourcen und Materialtechnik. RWTH Aachen University, Aachen, pp. 125

Bahlis, A.B., De Ros, L.F., 2013. Origin and impact of authigenic chlorite in the Upper Cretaceous sandstone reservoirs of the Santos Basin, eastern Brazil. Pet. Geosci. 19, 185-199. https://doi.org/10.1144/petgeo2011-007.

Billault, V., Beaufort, D., Baronnet, A., Lacharpagne, J.C., 2003. A nanopetrographic and textural study of grain-coating chlorites in sandstone reservoirs. Clay Miner. 38 (3), 315-328. https://doi.org/10.1180/0009855033830098.

Bjørlykke, K., 2014. Relationships between depositional environments, burial history and rock properties. Some principal aspects of diagenetic process in sedimentary basins. Sediment. Geol. 301, 1-14. https://doi.org/10.1016/j.sedgeo.2013.12.002.

Bloch, S., Lander, R.H., Bonnell, L.M., 2002. Anomalously high porosity and permeability in deeply buried sandstone reservoirs: origin and predictability. AAPG Bull. 86, 301-328. https://doi.org/10.1306/61EEDABC-173E-11D7-8645000102C1865D.

Busch, B., Hilgers, C., Gronen, L., Adelmann, D., 2017. Cementation and structural diagenesis of fluvio-aeolian Rotliegend sandstones, northern England. J. Geol. Soc. 174, 855-868. https://doi.org/10.1144/jgs2016-122.

Busch, B., Hilgers, C., Lander, R.H., Bonnell, L.M., Adelmann, D., 2018. Reservoir quality and burial model evaluation by kinetic quartz and illite cementation modeling: case study Rotliegendes, N-Germany. AAPG Bull. 101 (2), 293-307. https://doi.org/10. 1306/0503171605217075.

Civan, 2007. Reservoir Formation Damage.

Clauer, N., Liewig, N., Zwingmann, H., 2012. Time-constrained illitization in gas-bearing Rotliegende (Permian) sandstones from northern Germany by illite potassium-argon dating. AAPG Bull. 96 (3), 519-543. https://doi.org/10.1306/07131111003.

Darbha, G.K., Fischer, C., Luetzenkirchen, J., Schafer, T., 2012. Site-specific retention of colloids at rough rock surfaces. Environ. Sci. Technol. 46 (17), 9378-9387. https:// doi.org/10.1021/es301969m.

De Ros, L.F., Anjos, S.M.C., Morad, S., 1994. Authigenesis of amphibole and its relationship to the diagenetic evolution of Lower Cretaceous sandstones of the Potiguar rift basin, northeastern Brazil. Sediment. Geol. 88, 253-266. https://doi.org/10. 1016/0037-0738(94)90065-5

Deutsche Stratigraphische Kommission, 2002. Stratigraphische Tabelle von Deutschland 2002. Deutsche Stratigraphische Kommission (DSK); Potsdam (GeoForschungsZentrum); Frankfurt a. M. (Forsch.-Inst. Senckenberg).

Dowey, P., 2012. Prediction of Clay Minerals and Grain-Coatings in Sandstone Reservoirs Utilising Ancient Examples and Modern Analogue Studies. University of Liverpool, Liverpool.

Dowey, P.J., Hodgson, D.M., Worden, R.H., 2012. Pre-requisites, processes, and prediction of chlorite grain coatings in petroleum reservoirs: a review of subsurface examples. Mar. Pet. Geol. 32 (1), 63-75. https://doi.org/10.1016/j.marpetgeo.2011. 11.007.

Dowey, P.J., Worden, R.H., Utley, J., Hodgson, D.M., 2017. Sedimentary controls on modern sand grain coat formation. Sediment. Geol. 353, 46-63. https://doi.org/10. 1016/j.sedgeo.2017.03.001.

Duin, E.J.T., Doornenbal, J.C., Rijkers, R.H.B., Verbeek, J.Q., Wong, T.E., 2006. Subsurface structure of The Netherlands- results of recent onshore and offshore mapping. Neth. J. Geosci. 85 (4), 245-276. https://doi.org/10.1017/ S0016774600023064.

Ehrenberg, S.N., 1991. Kaolinized, potassium-leached zones at the contacts of the Garn Formation, Haltenbanken, mid-Norwegian continental shelf. Mar. Pet. Geol. 8 (3), 250-269.

Ehrenberg, S.N., 1993. Preservation of anomalously high porosity in deeply buried sandstones by grain-coating chlorite: examples from the Norwegian continental shelf. AAPG Bull. 77, 1260-1286. https://doi.org/10.1306/BDFF8E5C-1718-11D78645000102C1865D.

El-Ghali, M.A.K., Mansurbeg, H., Morad, S., Al-Aasm, I., Ajdanlisky, G., 2006. Distribution of diagenetic alterations in fluvial and paralic deposits within sequence stratigraphic framework: evidence from the petrohan terrigenous group and the svidol formation, lower triassic, NW Bulgaria. Sediment. Geol. 190 (1-4), 299-321. https://doi.org/10. 1016/j.sedgeo.2006.05.021.

Elias, A.R.D., De Ros, L.F., Mizusaki, A.M.P., Anjos, S.M.C., 2004. Diagenetic patterns in eolian/coastal sabkha reservoirs of the Solimões Basin, Northern Brazil. Sediment. Geol. 169 (3-4), 191-217. https://doi.org/10.1016/j.sedgeo.2004.06.001.

Esch, W.L., Ajdukiewicz, J.M., Reynolds, A.C., 2008. Early Grain-Coat Formation in Chaco Dune Field, New Mexico: Insight into Formation Mechanisms, Distribution, and Implications for Predictive Modeling to Assist in Deep Play Identification (Abs). 
AAPG Annual Convention, San Antonio, TX, USA.

Fischer, C., Aurin, P., Darbha, G.K., Arp, G., 2013. Experimental approaches to the formation of early-diagenetic grain coats on quartz surfaces. Z. Dtsch. Ges. Geowiss. 164 (2), 225-236. https://doi.org/10.1127/1860-1804/2013/0030.

Folk, R.L., 1980. Petrology of Sedimentary Rocks. Hemphill Publishing Company, Austin, Texas, U.S.A.

French, M.W., Worden, R.H., 2013. Orientation of microcrystalline quartz in the Fontainebleau Formation, Paris Basin and why it preserves porosity. Sediment. Geol. 284-285, 149-158. https://doi.org/10.1016/j.sedgeo.2012.12.004.

Fryberger, S.G., Knight, R., Hern, C., Moscariello, A., Kabel, S., 2011. Rotliegend facies, sedimentary provinces, and stratigraphy, Southern Permian Basin UK and The Netherlands: a review with new observations. In: Grötsch, J., Gaupp, R. (Eds.), The Permian Rotliegend of the Netherlands. Society for Sedimentary Geology, Tulsa, Oklahoma, U.S.A., pp. 51-88.

Gast, R.E., Dusar, M., Breitkreuz, C., Gaupp, R., Schneider, J.W., Stemmerik, L., Geluk, M.C., Geißler, M., Kiersnowski, H., Glennie, K.W., Kabel, S., Jones, N.S., 2010. Rotliegend. In: Doornenbal, J.C., Stevenson, A.G. (Eds.), Petroleum Geological Atlas of the Southern Permian Basin Area. EAGE Publications BV, Houten, pp. 101-123.

Gaupp, R., Matter, A., Platt, J.D., Ramseyer, K., Walzebuck, J., 1993. Diagenesis and fluid evolution of deeply buried Permian (Rotliegend) gas reservoirs, northwest Germany. AAPG Bull. 77 (7), 1111-1128. https://doi.org/10.1306/BDFF8E0C-1718-11D7$8645000102 \mathrm{C} 1865 \mathrm{D}$

Gaupp, R., Okkerman, J.A., 2011. Diagenesis and reservoir quality of Rotliegend sandstones in the northern Netherlands-a review. In: Grötsch, J., Gaupp, R. (Eds.), The Permian Rotliegend of the Netherlands. SEPM Society for Sedimentary Geology, pp. 193-226.

George, G.T., Berry, J.K., 1994. A new palaeogeographic and depositional model for the Upper Rotliegend, offshore The Netherlands. First Break 12 (3), 147-158.

Glennie, K.W., 1982. Early permian (Rotliegendes) palaeowinds of the North Sea Sediment. Geol. 34, 245-265.

Glennie, K.W., 1983. Lower permian Rotliegend desert sedimentation in the North Sea area. In: Brookfield, M.E., Ahlbrandt, T.S. (Eds.), Eolian Sediments and Processes. Elsevier Science Publishers B.V., Amsterdam, pp. 521-541.

Grigsby, J.D., 2001. Origin and growth mechanism of authigenic chlorite in sandstones of the lower Vicksburg Formation, South Texas. J. Sediment. Res. 71 (1), 27-36. https://doi.org/10.1306/060100710027.

Haile, B.G., Hellevang, H., Aagaard, P., Jahren, J., 2015. Experimental nucleation and growth of smectite and chlorite coatings on clean feldspar and quartz grain surfaces. Mar. Pet. Geol. 68, 664-674. https://doi.org/10.1016/j.marpetgeo.2015.02.006.

Hammer, E., Mørk, M.B.E., Næss, A., 2010. Facies controls on the distribution of diagenesis and compaction in fluvial-deltaic deposits. Mar. Pet. Geol. 27 (8), 1737-1751. https://doi.org/10.1016/j.marpetgeo.2009.11.002.

Hasner, K., 2004. Untersuchungen an Hämatit-Tonmineralkrusten in Rotliegendensandsteinen des Norddeutschen Beckens, Friedrich Schiller Universität Jena. Friedrich Schiller Universität Jena, Jena.

Havenith, V.M.J., 2012. Diageneseevolution von Ober-Rotliegend II Sandsteinen eines Tight-Gas Feldes in Ostfriesland (NW Deutschland). In: Fakultät für Georessourcen und Materialtechnik. RWTH Aachen University, Aachen, pp. 187.

Heald, M.T., Larese, R.E., 1974. Influence of coatings on quartz cementation. J. Sediment. Petrol. 44 (4), 1269-1274. https://doi.org/10.1306/212F6C94-2B24-11D7$8648000102 \mathrm{C} 1865 \mathrm{D}$.

Henares, S., Caracciolo, L., Cultrone, G., Fernández, J., Viseras, C., 2014. The role of diagenesis and depositional facies on pore system evolution in a Triassic outcrop analogue (SE Spain). Mar. Pet. Geol. 51, 136-151. https://doi.org/10.1016/j. marpetgeo.2013.12.004

Katzung, G., 1975. Tektonik, Klima und Sedimentation in der Mitteleuropäischen SaxonSenke und in angrenzenden Gebieten. Z. Geol. Wiss. 3, 1453-1472.

Ketzer, J.M., Morad, S., Evans, R., Al-Aasm, I.S., 2002. Distribution of diagenetic alterations in fluvial, deltaic, and shallow marine sandstones, within a sequence stratigraphic framework. J. Sediment. Res. 72 (6), 760-774. https://doi.org/10.1306/ 042202720760 .

Khalifa, M.A., Morad, S., 2015. Impact of depositional facies on the distribution of diagenetic alterations in the Devonian shoreface sandstone reservoirs, Southern Ghadamis Basin, Libya. Sediment. Geol. 329, 62-80. https://doi.org/10.1016/j. sedgeo.2015.09.003

Lan, C., Yang, M., Zhang, Y., 2016. Impact of sequence stratigraphy, depositional facies and diagenesis on reservoir quality: a case study on the Pennsylvanian Taiyuan sandstones, northeastern Ordos Basin, China. Mar. Pet. Geol. 69, 216-230. https:// doi.org/10.1016/j.marpetgeo.2015.09.009.

Lanson, B., Beaufort, D., Berger, G., Bauer, A., Cassagnabère, A., Meunier, A., 2002. Authigenic kaolin and illitic minerals during burial diagenesis of sandstones: a review. Clay Miner. 37 (1), 1-22. https://doi.org/10.1180/0009855023710014.

Liewig, N., Clauer, N., 2000. K-Ar dating of varied microtextural illite in Permian gas reservoirs, northern Germany. Clay Miner. 35, 271-281. https://doi.org/10.1180/ 000985500546648

Lutz, M., Kaasschieter, J.P.H., van Wijhe, D.H., 1975. Geological Factors Controlling Rotliegend Gas Accumulations in the Mid-european Basin. 9th World Geological Petroleum Congress, Tokyo, Japan, pp. 93-103.

Mahaney, W.C., Netoff, D.I., Dohm, J., Hancock, R.G.V., Krinsley, D., 2010. Grain coatings: diagenesis of Jurassic sandstones in south-central Utah and implications for targeting fossil microbes on Mars. Sediment. Geol. 230 (1-2), 1-9. https://doi.org/ 10.1016/j.sedgeo.2010.06.015.

Marchand, A.M.E., Apps, G., Li, W., Rotzien, J.R., 2015. Depositional processes and impact on reservoir quality in deepwater Paleogene reservoirs, US Gulf of Mexico. AAPG Bull. 99 (09), 1635-1648. https://doi.org/10.1306/04091514189.

Matlack, K.S., Houseknecht, D.W., Applin, K.R., 1989. Emplacement of clay in sand by infiltration. J. Sediment. Petrol. 59 (1), 77-87. https://doi.org/10.1306/212F8F212B24-11D7-8648000102C1865D.

Menning, M., 1995. A numerical time scale for the Permian and Triassic periods: an integrated time analysis. In: Scholle, P.A., Peryt, T.M., Ulmer-Scholle, D.S. (Eds.), The Permian of Northern Pangea, Volume 1: Paleogeography, Paleoclimates, Stratigraphy. Springer, Berlin, pp. 77-97.

Molenaar, N., Felder, M., 2018. Clay cutans and the origin of illite rim cement: an example from the siliciclastic Rotliegend sandstone in the Dutch southern Permian Basin. J. Sediment. Res. 88 (5), 641-658. https://doi.org/10.2110/jsr.2018.33.

Molenaar, N., Vaznytè, J., Šliaupa, S., 2019. Aridisols in the Southern Permian Basin, key to understand clay cement distribution. Int. J. Earth Sci. https://doi.org/10.1007/ s00531-019-01769-9.

Morad, S., Al-Ramadan, K., Ketzer, J.M., De Ros, L.F., 2010. The impact of diagenesis on the heterogeneity of sandstone reservoirs: a review of the role of depositional facies and sequence stratigraphy. AAPG Bull. 94 (8), 1267-1309. https://doi.org/10.1306/ 04211009178.

Morad, S., Ketzer, J.M., De Ros, L.F., 2000. Spatial and temporal distribution of diagenetic alterations in siliciclastic rocks: implications for mass transfer in sedimentary basins. Sedimentology 47 (1), 95-120. https://doi.org/10.1046/j.1365-3091.2000.00007.x.

Moraes, M.A.S., De Ros, L.F., 1992. Depositional, infiltrated and authigenic clays in fluvial sandstones of the Jurassic Sergi Formation, Reconcavo Basin, northeastern Brazil. In: Houseknecht, D.W., Pittman, E.D. (Eds.), Origin, Diagenesis, and Petrophysics of Clay Minerals in Sandstones. SEPM, Tulsa, Oklahoma, U.S.A.

Mountney, N.P., Jagger, A., 2004. Stratigraphic evolution of an aeolian erg margin system: the Permian Cedar Mesa Sandstone, SE Utah, USA. Sedimentology 51 (4), 713-743. https://doi.org/10.1111/j.1365-3091.2004.00646.x.

Needham, S.J., Worden, R.H., McIlroy, D., 2005. Experimental production of clay rims by macrobiotic sediment ingestion and excretion processes. J. Sediment. Res. 75, $1028-1037$.

NLOG, 2018, Data by borehole, K10-14 (Well F), K10-B-04 (Well G): http://www.nlog. $\mathrm{nl} / \mathrm{nlog} /$ requestData/nlogp/allBor/metaData.jsp?table $=$ BorLocation\&id $=$ 106528155,106529999,106528798; K10-C-02 (Well H): http://www.nlog.nl/nlog/ requestData/nlogp/allBor/metaData.jsp?table $=$ BorLocation\&id $=106524379$, 106528888,106524387,106527148; K10-V-02 (Well I): http://www.nlog.nl/nlog/ requestData/nlogp/allBor/metaData.jsp?table $=$ BorLocation\&id $=106528155$, 106529999,106528798; K13-DE-03 (Well J): http://www.nlog.nl/nlog/requestData/ nlogp/allBor/metaData.jsp?table $=$ BorLocation \&id $=106524655,106526846$, $106526840,106524643,106524649,294886125$ 15.03.2019.

Paxton, S.T., Szabo, J.O., Ajdukiewicz, J.M., Klimentidis, R.E., 2002. Construction of an intergranular volume compaction curve for evaluating and predicting compaction and porosity loss in rigid-grain sandstone reservoirs. AAPG Bull. 86 (12), 2047-2067. https://doi.org/10.1306/61EEDDFA-173E-11D7-8645000102C1865D.

Pittmann, E.D., Larese, R.E., Heald, M.T., 1992. Clay coats : occurrence and relevance to preservation of porosity in sandstones. In: Houseknecht, D.W., Pittmann, E.D. (Eds.), Origin, Diagenesis, and Petrophysics of Clay Minerals in Sandstones SEPM Special Publication, Tulsa, Oklahoma, U.S.A. pp. 241-256.

Platt, J.D., 1993. Controls on clay mineral distribution and chemistry in the early Permian Rotliegend of Germany. Clay Miner. 28, 393-416. https://doi.org/10.1180/claymin. 1993.028.3.05.

Ramm, M., 2000. Reservoir quality and its relationship to facies and provenance in Middle to Upper Jurassic sequences, northeastern North Sea. Clay Miner. 35, 77-94. https://doi.org/10.1180/000985500546747.

Remy, R.R., 1994. Porosity reduction and major controls on diagenesis of CretaceousPaleocene volcaniclastic and arkosic sandstone, Middle Park Basin, Colorado. J. Sediment. Res. A64 (4), 797-806. https://doi.org/10.1306/D4267EC9-2B26-11D78648000102C1865D.

Rieke, H., 2001. Sedimentologie, Faziesarchtektur und Faziesentwicklung des kontinentalen Rotliegenden im Norddeutschen Becken, GeoForschungsZentrum. University of Potsdam, Potsdam, pp. 337.

Rogers, J.J.W., Head, W.B., 1961. Relationships between porosity, median size, and sorting coefficients of synthetic sands. J. Sediment. Petrol. 31 (3), 467-470. https:// doi.org/10.1306/74D70BA5-2B21-11D7-8648000102C1865D.

Roos, B.M., Smits, B.J., 1983. Rotliegend and main Buntsandstein gas fields in Block K/ 13; a case history. Geol. en Mijnbouw. Neth. J. Geosci. 62 (1), 75-82.

Ryan, P., Reynolds, R., 1996. The origin and diagenesis of grain-coating serpentinechlorite in Tuscaloosa Formation sandstone, US Gulf Coast. Am. Mineral. 81 (1-2), 213-225. https://doi.org/10.2138/am-1996-1-226.

Schöner, R., Gaupp, R., 2005. Contrasting red bed diagenesis: the southern and northern margin of the Central European Basin. Int. J. Earth Sci. 94 (5-6), 897-916. https:// doi.org/10.1007/s00531-005-0004-3.

Seemann, U., 1982. Depositional facies, diagenetic clay minerals and reservoir quality of Rotliegend sediments in the southern Permian Basin (North Sea): a review. Clay Miner. 17, 55-67. https://doi.org/10.1180/claymin.1982.017.1.06.

Shammari, S., Franks, S., Soliman, O., 2011. Depositional and Facies Controls on Infiltrated/Inherited Clay Coatings: Unayzah Sandstones, Saudi Arabia. AAPG Annual Convention and Exhibition, Houston, Texas, USA.

Storvoll, V., Bjørlykke, K., Karlsen, D., Saigal, G., 2002. Porosity preservation in reservoir sandstones due to grain-coating illite: a study of the Jurassic Garn Formation from the Kristin and Lavrans fields, offshore Mid-Norway. Mar. Pet. Geol. 19, 767-781. https://doi.org/10.1016/S0264-8172(02)00035-1.

Taylor, T., Stancliffe, R., Macaulay, C., Hathon, L., 2004. High temperature quartz cementation and the timing of hydrocarbon accumulation in the Jurassic Norphlet sandstone, offshore Gulf of Mexico, USA. In: Cubitt, J.M., England, W.A., Larter, S. (Eds.), Understanding Petroleum Reservoirs: towards an Integrated Reservoir Engineering and Geochemical Approach. Geological Society, London, pp. 257-278.

Trask, P.D., 1930. Mechanical analysis of sediment by centrifuge. Econ. Geol. 25, 
581-599.

Vackiner, A.A., 2011. Sedimentary facies reconstruction and kinematic restoration of an Upper Permian tight gas field, north-western Germany. In: Fakultät für Georessourcen und Materialtechnik. RWTH Aachen University, Aachen, pp. 144.

van den Belt, F.J.G., van Hulten, F.F.N., 2011. Sedimentary architecture and palaeogeography of Lower Slochteren aeolian cycles from the Rotliegend desert-lake margin (Permian), the Markham area, southern North Sea. In: Grötsch, J., Gaupp, R. (Eds.), The Permian Rotliegend of the Netherlands. Society for Sedimentary Geology, Tulsa, Oklahoma, U.S.A.

Van Keer, I., Muchez, P., Viaene, W., 1998. Clay mineralogical variations and evolutions in sandstone sequences near a coal seam and shales in the Westphalian of the Campine Basin (NE Belgium). Clay Miner. 33 (1), 159-169. https://doi.org/10.1180/ 000985598545345.

Verweij, H., 2003. Fluid flow systems analysis on geological timescales in onshore and offshore Netherlands. With special reference to the Broad Fourteens Basin, Faculteit der Aard- en Levenswetenschappen. Vrije Universiteit Amsterdam, pp. 290.

Walderhaug, O., 1996. Kinetic modelling of quartz cementation and porosity loss in deeply buried sandstone reservoirs. AAPG Bull. 80, 731-745. https://doi.org/10. 1306/64ED88A4-1724-11D7-8645000102C1865D.

Walker, T.R., 1979. Red color in dune sands. In: McKee, E.D. (Ed.), A Study of Global Sand Seas. U.S. Government Printing Office, Washington, D. C., pp. 61-81.

Welton, J., 2015. Impact of Microbes on Reservoir Quality (abs.). AAPG Annual Convention and Exhibition, Denver, CO, U.S.A.

Wilson, M.D., 1992. Inherited grain-rimming clays in sandstones from eolian and shelf environments : their origin and control on reservoir properties. In: Houseknecht, D.W., Pittman, E.D. (Eds.), Origin, Diagenesis, and Petrophysics of Clay Minerals in Sandstone. SEPM Special Publications, Tulsa, Oklahoma, U.S.A., pp. 282.

Wooldridge, L.J., Worden, R.H., Griffiths, J., Utley, J.E.P., 2017. Clay-coated sand grains in petroleum reservoirs: understanding their distribution via a modern analogue. J. Sediment. Res. 87 (4), 338-352. https://doi.org/10.2110/jsr.2017.20.

Wooldridge, L.J., Worden, R.H., Griffiths, J., Utley, J.E.P., 2019a. How to quantify claycoat grain coverage in modern and ancient sediments. J. Sediment. Res. 89 (2), 135-146. https://doi.org/10.2110/jsr.2019.6.

Wooldridge, L.J., Worden, R.H., Griffiths, J., Utley, J.E.P., Sheldon, N., 2019b. Clay-coat diversity in marginal marine sediments. Sedimentology. https://doi.org/10.1111/ sed.12538.

Worden, R.H., Burley, S.D., 2003. Sandstone Diagenesis: the Evolution of Sand to Stone, Sandstone Diagenesis. Blackwell Publishing Ltd., pp. 1-44.

Worden, R.H., Morad, S., 2002. Clay minerals in sandstones: controls on formation, distribution and evolution. In: Worden, R.H., Morad, S. (Eds.), Clay Mineral Cements in Sandstones. Blackwell Science Ltd, Oxford, pp. 3-42.

Wüstefeld, P., Hilse, U., Lüders, V., Wemmer, K., Koehrer, B., Hilgers, C., 2017. Kilometerscale fault-related thermal anomalies in tight gas sandstones. Mar. Pet. Geol. 86, 288-303. https://doi.org/10.1016/j.marpetgeo.2017.05.015.

Zwingmann, H., Clauer, N., Gaupp, R., 1998. Timing of fluid flow in a sandstone reservoir of the north German Rotliegend (Permian) by K-Ar dating of related hydrothermal illite. In: Parnell, J. (Ed.), Dating and Duration of Fluid Flow and Fluid-Rock Interaction. Geological Society, London, Special Publications, pp. 91-106. 
Karlsruher Institut für Technologie

\section{Repository KITopen}

Dies ist ein Postprint/begutachtetes Manuskript.

Empfohlene Zitierung:

Busch, B.; Hilgers, C.; Adelmann, D.

Reservoir quality controls on Rotliegend fluvio-aeolian wells in Germany and the

Netherlands, Southern Permian Basin - Impact of grain coatings and cements. 2020. Marine and petroleum geology, 112.

doi: $10.5445 / / R / 1000099093$

Zitierung der Originalveröffentlichung:

Busch, B.; Hilgers, C.; Adelmann, D.

Reservoir quality controls on Rotliegend fluvio-aeolian wells in Germany and the Netherlands, Southern Permian Basin - Impact of grain coatings and cements. 2020. Marine and petroleum geology, 112, Art.-Nr.: 104075.

doi:10.1016/j.marpetgeo.2019.104075 